\title{
TOWARD A THEORY OF COPYRIGHT: THE METAMORPHOSES OF "AUTHORSHIP"
}

\author{
Peter JASzi*
}

\section{INTRODUCTION}

This Article is about "authorship," which is arguably the most central, and certainly the most resonant, of the foundational concepts associated with Anglo-American copyright doctrine. But discussions of copyright doctrine tend to assume the importance of "authorship" as a privileged category of human enterprise, rather than to examine where this notion arose or how it has influenced the law. In what follows, I try to show how copyright received a constructed idea of "authorship" from hiterary and artistic culture and to explore ways-sometimes peculiar and even perverse ways-in which this "authorship construct" has been mobilized in legal discourse.

The "author" has been the main character in a drama played out on the parallel stages of hiterary and legal culture. By the mid-seventeenth century, well before the Enghish enacted the 1709 Statute of Anne ${ }^{1}$, writers began to assert claims to special status by designating themselves as "authors." During the eighteenth century, "authorship" becaine intimately associated with the Romantic movement in hiterature and art, expressing "an extreine assertion of the self and the value of individual experience ... together with the sense of the infinite and the transcendental."2 Until very recently, the position of the "author" as a category in literary criticism was:

central not only in theory but in practice: in the way single-figure studies dominate criticisin; in the organization of texts in "coinplete editions"; in biographies; and above all, in the idea of style, of a marked writing characteristically the "expression" of a person's

Copyright (C) Peter Jaszi 1991.

* 1991 Professor of Law, Washington College of Law, The American University, Washington, D. C. An early version on this Article was delivered as a paper at the April 1990 ineeting of the American Society for Eighteenth Century Studies. Work on revisions was supported by a generous summer research grant from the Washington College of Law. Absent Martha Woodmansee's exemplary seholarship, I would never have conceived of the projeet; were it not for James Boyle's intellectual generosity, I would not have pursued it; and without Elliott Milstein's encouragement, I would never have finished. I thank them all-and I dedicate this to Sheryl.

1. 1709, 8 Anne, ch. 21.

2. The OXford Companion to English Literature 842 (M. Drabble 5th ed. 1985). The Companion also notes that "[t]he styhistic keynote of Romanticisin is intensity, and its watclıword is 'Imagination.' " Id. at 843. 
"mind" or "psyche" whose essential identity scrawls across a page and declares its imaginative "ownership" of these self-revealing and selfconstituting lines. ${ }^{3}$

Law's reception of "authorship" began well before the heyday of Romanticism in the late eighteenth and early nineteenth centuries. But I try to show that it is not coincidental that precisely this period saw the articulation of many doctrinal structures that dominate copyright today. In fact, British and American copyright presents inyriad reflections of the Romantic conception of "authorship"--even if they sometimes remind one of images in fun-house mirrors.

In what follows, I intend to disaggregate the concept of "authorship" in copyright by analyzing some of the legal texts in which it is deployed and by examining the cultural contexts froin which it was absorbed into legal discourse. This analysis will show how the "authorship" concept, although highly visible in conteinporary copyright law, usually appears as a focus of consensus rather than debate. "Authorship," as deployed in texts and in cultural understandings, has been anything but a stable, inert foundation for the structure of copyright doctrine. Rather, the ideologically charged concept has been an active shaping and destabilizing force in the erection of that structure.

Although this Article examines a series of episodes in the history of copyright, it is not a historical survey, and it says hittle about what the content of copyright law should be. I do not attempt to reconcile and rationalize contradictory features of copyright doctrine in terns of formal categories or underlying pohicies. Instead, I analyze the incoherencies of copyright doctrine from several external perspectives-most notably, modern hiterary theory.

Broadly speaking, iny attack on "authorship" aspires to "deconstruct": I einphasize the unresolved multifariousness of the concept and "the power of language and its ability to say unore than it biterally pretends to say."4 Methodology aside, however, my objectives may be less

3. Bové, Discourse, in Critical Terms for LITERARY Study 63 (F. Lentricchia \& T. McLauglin eds. 1990).

4. U. Eco, Unlimited Semiosis and Drift: Pragmaticism vs. "Pragmatism," in THE LIMrTs OF INTERPRETATION 23, 33 (1990). Describing the work of Jaques Derrida, the leading figure in "deconstructive criticism," Eco states that Derrida "wants to establish a practice (whieh is philosophical more than critical) for challenging those texts that look as though dommated by the idea of a definite, final, and authorized meaning." Id. The "deconstructive" techmique, then, inherently calls all notions of "authorship" into question.

Another recent comment describes "deconstruction" as follows: "Deconstruction is a twofold strategy of, on the one hand, uncovering and undoing logocentric rationality and on the other, drawing attention to the language of the text, to its figurative and rhetorical gestures and pointing up the text's existence in a web of textuality ...." Rice \& Waugh, Language and Textuality, in MODERN LITERARY THEORY: A READER 147, 148 (P. Rice \& P. Waugh eds. 1989). 
than completely true to the aims of deconstruction. My emphasis on the role of ideology in the story of "authorship" suggests general "post-structuralist," rather than specifically deconstructiomst tendencies, ${ }^{5}$ and my focus on the patterns of opposition out of which meaning is generated in copyright doctrine are characteristic of structuralisin itself. ${ }^{6}$

The Article begins with a discussion of the limitations of conventional structuralist analysis to make sense of the confusion of copyright doctrine. It moves away from the consideration of the structure of that doctrine to confront "authorship" in a series of contextualized "close readings." I point out how the "authorship" concept has operated to conceal, rather than to reveal, the actual stakes in the ongoing discussions of "literary property" and how the multiple functions of "authorship" continue to generate incoherence in copyright doctrine. I then discuss how "autliorship" lias been continually revived and redeployed, sometimes under very unusual circumstances, in debates about the doctrinal features of copyright protection. Finally, I explain the unusual power and persistence of "authorship," demonstrating that far from being a non-controversial, generalized "source" of copyright doctrine, it in fact is the specific locus of a basic contradiction between public access to and private control over imaginative creations. This inquiry into "autliorship" aims to demonstrate tlie tension between two different visions of the individual's place in the community-one a characteristic of early modern, pre-industrial social tliought and the other associated with postindustrial ideology.

If all of this sounds a trifle metaphysical, recall that Justice Story said that patent and copyright cases come "nearer than any other class of cases belonging to forensic discussions, to what may be called the metapliysics of the law where the distinctions are, or at least inay be, very subtle and refined, and, sometimes, almost evanescent."7 Indeed, it is something of a mystery that legal scholars in the Umited States and Great Britain have not previously sought to "read" the literature of copyright in this manner. Although legal academics have applied the methodologies of "textual criticisin" to many other sorts of legal materials, ${ }^{8}$ they

5. More specifically, my efforts to draw out homologous relationships between developments in law and developments in literary culture-without insisting that one is somehow determined by the other-have something in common with the techmiques of "New Historicism." See S. GrEENBLATT, SHAKESPEAREAN NEGOTIATIONS 5 (1988) (describing his critical techmique as a "poetics of culture").

6. See D. LODGE, WorkING WITH STRUCTURALISM ix (1981).

7. Folsom v. Marsh, 9 F. Cas. 342, 344 (C.C.D. Mass. 1841) (No. 4901).

8. See G. Frug, The City as a Legal Concept, 93 HARv. L. REv. 1057 (1980) (criticism of the way in which liberal social theory has contributed to the powerlessness of modern cities); M. Frug, Re-Reading Contracts: A Feminist Analysis of a Contracts Casebook, 34 AM. U.L. REv. 1065 (1985) 
have left the body of copyright doctrine largely unexamined-despite the fact that copyright constitutes, so to speak, the law of "texts."9

Legal scholars concerned with copyright occupy themselves not by analyzimg copyright theory, but instead by debating the rights and wrongs of technical doctrinal issues presented by judicial opinions. ${ }^{10}$

(demonstrating the gendered aspects of a first-year, law student's contracts casebook); Kelman, Interpretive Construction in the Substantive Criminal Law, 33 STAN. L. Rev. 591 (1981) (critical analysis of standard doctrinal arguments in criminal law); Kennedy, The Structure of Blackstone's Commentaries, 28 Bufralo L. REV. 205 (1979) (a neo-Marxist analysis of Blackstone's Commentaries on the Laws of England); see generally Boyle, The Politics of Reason: Critical Legal Theory and Local Social Thought, 133 U. PA. L. REV. 685 (1985) (describing and explaining the theories cinployed by critical legal scholars); Gordon, New Developments in Legal Theory, in THE PoLITICs of LAW: A Progressive CrITIQue 281 (D. Kairys ed. 1982) (suggesting reasons why radical legal scholars have applied deconstructive textual strategies to traditional legal subjects). The importance of these developments has been summed up by Stanley Fish (a Professor of English at Duke University):

[R]ecent years have seen an unprecedented traffic between legal and literary studies ....

Not only is it now difficnlt to tell some numbers of the Stanford Law Review or The Yale

Law Journal from Diacrities or Critical Inquiry, but the issues debated in their pages have spilled out into tenure battles, the restructuring of curricula and even of whole law schools, and produced a general sense in the legal profession of a new crisis in which its authorityinternal and external-is being put into question as never before.

S. Fish, Don't Know Much about the Middle Ages: Posner on Law and Literature, in DoING What Comes Naturally: Change, Rhetoric, and the Practice of Theory in Literary and LEGAL STUDIES 294, 307 (1989).

9. The "text" is the central concept of modernist critical theory-what Roland Barthes defines as "a work conceived, perceived and received in its iutegrally symbohic nature ...." Barthes, From Work to Text, in IMAGE, Music, Text 159 (S. Heath trans. 1977) (emphasis omitted). The "text" may be literary, visual, or aural (or any combination of these); whatever form it takes, it is created not in the act of writing but in the act of reading. It "asks of the reader a practical collaboration." Id. at 163. Although copyright is concerned at the threshold with the protection of "works of authorship," copyright doctrine also determines the permissible range of "uses"—or "readings"that may be made of particular "texts." See, e.g., Stewart v. Abend, 110 S. Ct. 1750, 1758-65 (1990) (continued exhibition of authorized "derivative" motion picture infringes copyriglut in "underlying" novel, where renewal copyriglt in novel has been claimed by its authors" "statutory successor").

10. Sometimes they take the stance of legal fornalists, working from the imphicit assumption that doctrine has an inherent, colierent patterning that can be revcaled and clarified through application and effort. Sometimes they venture so far as to incorporate references to the rcal or supposed constitutional purposes of the copyright system into their doctrinal discussions, concluding that particular doctrinal developments do or do not fulfill those purposes.

One indication of the "poverty of theory" in which copyriglat is concerned is that even the analytic techniques of "legal realism," with its emphasis on understanding the function of doctrine in social and economic life, lave gone largely unapplied where copyright is concerned. Thus, in Felix Colien's remarkable essay, Transcendental Nonsense and the Function Approach, 35 CoLUM. L. ReV. 809, 814-17 (1935), the circularity of the premises of English and American trademark doctrine is exposed, but parallel features of copyright are not considered.

There have, of course, been thouglutful, provocative, and even prophetic writings on copyright by American legal scholars. See, e.g., B. KAPLAN, AN UNHURRIED VIEW OF CopYright (1967); L. Patterson, Copyright in Historical Perspective (1968). Both Kaplan and Patterson approach the subject as lawyers whose primary interest is the clarification and rectifieation of doctrine througlh the elucidation of its historical and cultural context; their often inasterful exegeses of the sources of doctrine are mcans to other ends. 
Legal scholars' failure to theorize copyright relates to their tendency to mythologize "authorship," leading them to fail (or refuse) to recognize the foundational concept for what it is-a culturally, pohtically, economically, and socially constructed category rather than a real or natural one. Lawyers who are happy to admit (for example) that "neghigence" is such a construct seem blind to the fact that "authorship" is as well. Inevitably, those lawyers and scholars recur to the "authorship" concept, seemingly einbracing the whole complex set of values and associations that attached to the notion of "authorship" during its emergence in the Romantic period-and in particular the Wordsworthian vision of the "author-geinus" with privileged access to the numinous. ${ }^{11}$

There has been some notable work, utilizing Marxist perspectives, on the theory of "authors" rights" doctrine in Europe. See, eg., B. EDELMAN, OWNERSHIP OF THE IMAGE: ElEMENTS For A MARXIST THEORY OF LAW (E. Kingdom trans. 1979). Among Edelman's subjects is the manipulation of the "authorship" concept to achieve the necessary conditions for the efficient legal exploitation of works of collective/cooperative labor. Legal scholars have not yet brought this work to directly bear on the Anglo-American copyright tradition, although there is some useful hiterature on analyzing patent law from a Marxist perspective. See Armstrong, From the Fetishism of Commodities to the Regulated Market: The Rise and Decline of Property, 82 Nw. U.L. REv. 79 (1987) (testing a Marxist model of the rise and decline of property against the history of patent law).

An exception to my characterization of American copyright as generally "undertheorized" is offered by the work of legal academics of the "law and economics" school. See, e.g., Gordon, Fair Use as Market Failure: A Structural and Economic Analysis of the Betamax Case and its Predecessors, 82 ColUM. L. REV. 1600 (1982) (applying "market approach" to criticize the Nimth Circuit's "fair use" analysis in the Betamax case); Landes \& Posner, An Economic Analysis of Copyright Law, 18 J. LEGAL STUD. 325 (1989) (applying microeconomic modelling to explain and rationalize features of copyright doctrine); Menell, Tailoring Legal Protection for Computer Software, 39 STAN. L. REV. 1329 (1987) (analyzing software copyright as a classic "public goods" problem). More interesting still are Wendy Gordon's recent articles outlining, inter alia, the limitations of a "law and economics" approach in understanding the copyright system. See Gordon, An Inquiry into the Merits of Copyright: The Challenges of Consistency, Consent, and Encouragement Theory, 41 STAN. L. Rev. 1343 (1989) (questioning the premises on which economic tests of copyright law are founded); Gordon, Toward a Jurisprudence of Benefits: The Norms of Copyright and the Problem of Private Censorship, 57 U. CHI. L. REv. 1009 (1990)) (critiquing some of the economic methodologies used by Paul Goldstein in his treatise CopYrIGHT: PRINCIPLES, LAw AND PRACTICE (1989)) [hereinafter Gordon, Toward a Jurisprudence of Benefits].

More generally, the tide seems to be turning. Although some interesting recent writing treating copyright theory has not addressed the structure of doctrine in any detail, see, e.g., Hughes, The Philosophy of Intellectual Property, 77 GEO. L.J. 287 (1989) (a description of Lockean "labor theory" and Hegelian "personality theory" justifications for ascribing the ownership of intellectual property), Jane Ginsberg's article, Creation and Commercial Value: Copyright Protection for Works of Information, 90 ColUM. L. REV. 1865 (1990), represents a ground-breaking effort at prescriptive application of a historically-derived theoretical model of copyright and Alfred Yen's Restoring the Natural Law: Copyright as Labor and Possession, 52 OHIo ST. L.J. 517 (1990), discusses the specific implication of Lockean analysis of entitlement for copyright doctrine. Both Gordon's Toward a Jurisprudence of Benefits, supra, at 1028-32, and Jessica Litınan's The Public Domain, 39 EMORY L.J. 965, 1007-11 (1990), include important discussions of the somewhat inimical relationship between the Romantic model of "authorship" and the realities of the creative process.

11. For a complete description of this conception of "authorship," and an account of its origins, see Woodmansee, The Genius and the Copyright: Economic and Legal Conditions of the Emergence 
A recent decision written by Judge Richard Posner illustrates this point. ${ }^{12}$ The case involved the question of the appropriate standards of copyrightability for "derivative works." The 1976 Copyright Act defines this term as "a work based upon one or inore preexisting works, such as a translation, inusical arrangeinent, dramatization . . . art reproduction ... or any other form in which a work nay be recast, transformed, or adapted."13 And, as Jessica Litınan recently noted, inost works are, at least partially, derivative: "The process of authorship ... is inore equivocal than ... [the Romantic vision] admits. To say that every new work is in some sense based on the works that preceded it is such a truisin that it has long becn a chiché, invoked but not examined."14 The question of

of the 'Author,' 17 EIGHTEENTH-CENTURY STUD. 425, 428-30 (1983-1984) (detailing the Romantic conviction that the "author-gemus" was someone who created something entirely new and unprecedented). The theoretical underpinnings of the English Romantics" "exaltation of the poet and the world of hiterature" are discussed in P. PARRINDER, AUTHORS AND AUTHORITY: A STUDY OF ENGLISH LTTERARY CRITICISM AND ITS RELATION TO CULTURE 1750-1990, at 52 (1977). For an extended discussion, see id. at 32-53. The importance to the Romantic credo of faculty of "imagination," possession of which gave true poets-the paradigmatic "authors"-their special calling, has been discussed in S. GiLL, WILLIAM Wordsworth: A LIFE 237-39 (1989), and R. Holmes, COLERIDGE: EARLY VISIONS $170 \mathrm{n} *$, 217-18 (1990). The emergence into importance of the related ideal of "originality" is traced with particular reference to Edward Young's 1759 essay Conjectures on Original Composition in B. KAPLAN, supra note 10, at 27, and in Jaszi, When Works Collide: Derivative Motion Pictures, Underlying Rights, and the Public Interest, 28 UCLA L. REV. 715, 730 n.33 (1981).

12. Gracen v. Bradford Exch., 698 F.2d 300 (7th Cir. 1983). As the father of the "law and economics" movement, Judge Posner should know better. The "law and economics" movement holds that legal doctrine is essentially an instrument to serve and promote the operation of free tnarkets. Thus, the merit of any legal rule should be evaluated in terms of whether it tends to promote the "efficient" allocation of resources. Followers of the movement pride theinselves on their willingness to apply their methodology to all bodies of legal doctrine, including those that one might assume should properly be shaped by non-econoimic considerations. See Landes \& Posner, The Economics of the Baby Shortage, 7 J. LEGAL STUd. 323 (1978) (advocating legalization of "black inarket" adoptions).

Quite apart from the fact that "law and economics" seems inimical to the Romantic vision of "authorship," Judge Posner has specifically questioned this aspect of Romanticism. See infra note 20. Here, consciously or unconscionsly, he embraces it.

13. 17 U.S.C. $\S 101$ (1988). Section 106(2) of the Act provides that the copyright owners' "exclusive rights" include the right "to prepare derivative works based upon the copyrighted work." Id. $\S 106(2)$. Copyright in a derivative work extends only to the authors' original contribution, and not to material taken by permission from protected underlying works, or from works in the public domain. Id. $\S 103(b)$. The "public domain" of works unprotected by copyright is valuable precisely because it provides the artistic commumity with a source it can draw upon for the creation of "derivative works." See generally Litman, supra note 10, at 965-69. The 1976 Act failed to resolve, or even to address, the most difficnit question of copyright law bearing on this important category of works: When is a derivative work (or as it was termed in section 7 of the 1909 Act, a "new work," see Act of Mar. 4, 1909, ch. 320, 35 Stat. 1075, 1080-81 (1909) (current version at 17 U.S.C. $\S \S 302$ 305 (1988))) entitled to a copyright in its own right?

14. Litman, supra note 10 , at 966 (citations oinitted). The quotation continues:

[T] he very act of authorship in any medium is more akin to translation and recombination than it is to creating Aphrodite from the foain of the sea. Composers recombine sounds 
when the recombination of preexisting elements produces a work which merits copyright protection is of major practical importance.

In Gracen v. Bradford Exchange, 15 Judge Posner considered the work of an artist who painted on porcelain plates images drawn from still photographs of scenes from the motion picture The Wizard of $\mathrm{Oz}^{16}$ One of the plates had the superimposed figure of Dorothy over an image of the yellow brick road. Rejecting the artist's claims to copyright in this painting, Judge Posner wrote: "We do not consider a picture created by superimposing one copyrighted photographic image on another to be 'original.' "17

The holding that the composite painting was insufficiently original to deserve copyright protection represented a considerable departure from traditional copyright doctrine ${ }^{18}$ and cannot be adequately explained in terms of the nominal justification offered by Judge Posner. ${ }^{19}$ Nor can

\begin{abstract}
they have heard before; playwrights base their characters on bits and pieces drawn from real human beings and other playwrights' characters; novelists draw their plots from lives and other plots within their experience; software writers use the logic they find in other software; lawyers transform old arguments to fit new facts; cinematographers, actors, choreographers, architects, and sculptors all engage in the process of adapting, transforming, and recombining what is already "out there" in some other form. This is not parasitism: it is the essence of authorship. And, in the absence of a vigorous public domain, much of it would be illegal.
\end{abstract}

Id. at 966-67 (citations omitted).

15. 698 F.2d 300 (7th Cir. 1983).

16. The Wizard of $\mathrm{Oz}$ (Metro-Goldwyn-Mayer 1939).

17. Gracen, 698 F.2d at 305. Posner was careful to add that "[i]f a painter paints from life, no court is going to hold that his painting is not copyrightable because it is an exact photographic likeness." Id.

18. Conventional accounts of the law of copyrightability in "derivative works" begin with Judge Frank's decision in the case of Alfred Bell \& Co. v. Catalda Fine Arts, Inc., 191 F.2d 99 (2d Cir. 1951), which identifies the requisite contribution of new inatter as "something more than ... "merely trivial." Id. at 103. This is a low threshold indeed. Althougl subsequent decisions have raised the threshold somewhat, see L. Batlin \& Son v. Snyder, 536 F.2d 486 (2d Cir.) (requiring a readily perceptible difference between the underlying work of art and the copy of it for which protection is sought), cert. denied, 429 U.S. 857 (1976), Gracen, with its statement that "a derivative work must be substantially different from the underlying work to be copyrightable," 698 F.2d at 305, represents a quantum leap.

The court retreated slightly from Gracen in Saturday Evening Post Co. v. Rumbleseat Press, 816 F.2d 1191 (7th Cir. 1987). Saturday Evening Post involved porcelain copies of Norman Rockwell illustrations, and Judge Posner himself stated that derivative works are "copyrightable provided the derivative work has some incremental originality . . . " Id. at 1193 .

19. Judge Posner explains his Gracen decision in terms of an asserted need to prevent public confusion as to the copyright status of the works that underlie derivative productions. Gracen, 698 F.2d at 304-05. In fact, however, the relatively permissive Alfred Bell standard for derivative work copyrightability, see supra note 18, from which Judge Posner diverged in Gracen, is sufficient to avoid the evil he identifies. As long as a derivative work is "distinguishable" from the underlying one on which it is based, as the Alfred Bell test requires, there should be no risk of such confusion or deception. See generally Oppenheimer, Originality in Art Reproductions: "Variations" in Search of a Theme, 27 COPYRIGHT L. SYMP. (ASCAP) 207 (1982). 
the holding be easily justified under a free market ideology of law and economics. ${ }^{20}$

The decision does make sense, however, when viewed in light of the Romantic "authorship" construct, with its imphicit recognition of a hierarchy of artistic productions. In that hierarchy, art contains greater value if it results from true imagination rather than mere application, particularly if its creator draws imspiration directly from nature. ${ }^{21}$ In the

20. Seemingly, at least, the goals of the "law and economics" theory might be well served by awarding copyright protection berally and allowing worthy artistic productions to prove their claims over inferior ones in the marketplace. In a recent book, Judge Posner advances a number of economic arguments for limiting the number of works protected by copyright as well as the scope of copyright protection, stating that "the most serious objection to an expansion of copyright protection is that the expansion might reduce the output of literature by increasing the royalty expense of writers." R. Posner, LAw and Literature: A Misunderstood Relation 343 (1988). This argument, lowever, does not seem to bear on the particular limitation on copyright for derivative works that Judge Posner devised in Gracen. In a inore recent article, Judge Posner explains:

For obvious reasous, the derivative work must have some expressive elements not found in the original work; otherwise it would be identical to the original work. Suppose the derivative work is a wind-up Mickey Mouse doll that looks just like the copyrighted Mickey Mouse comic strip character; the commercial success of the doll depends on its being an exact replica of the Walt Disney character. Since this mechanical "translation" of the figure into a new medium involves no expression, copyright protection is not required to prevent free riding by third parties ....

Landes \& Posner, supra note 10, at 355-56 (citations omitted). This characterization of that which coustitutes protectible expression seems, lowever, to proceed from a value judginent rather than from economic analysis.

In the same article, Judge Posner offers several questionable economic justifications for the holding in Gracen. First, he argues that limiting the copyrightability of derivative works minimizes the so-called "transaction costs" associated with various sources of non-productive friction in the economic system, including litigation: "Some courts have required that the increment [of new expression] be significant, worrying that if it is set too low, and if the original and derivative copyrights liappen to be in different hands ... the costs of determining infringement could be prohibitive." Id. at 356. This seems to be no more than a restatement of the rationale of Gracen itself. Moreover, it assumes incorrectly that the problem of proof could not be solved through the use of expert testimony.

His second justification is of a different character, and it includes a curious reservation: "In addition, if the original and derivative works are barely distinginshable . . . the benefits of legal protection in encouraging the creation of new and distinct works nay be trivial. But in making this point we are abstracting from the case, illustrated by photography of works of art, where the creativity of the derivative work cousists precisely in the fidelity with which it reproduces the inpression created by the original." Id. at 356-57. This seems like an invitation to courts to assess the valuethat is, the quality - of the new "authorship" in assessing the copyrightability of a derivative work. Further, it suggests that Judge Posner might apply one test to paintings on china plates and another-perhaps the Alfred Bell formula itself-to art reproductions.

21. William Wordswortl was instrumental in fostering the Rounantic cult of "imagination," and his long poem, The Prelude, is a celebration of this authorial faculty. Wordswortl, The Prelude, Bk. XIII (1805). A recent biograpler has written that in The Prelude, "[i]magination is presented as the power that enables Man to convert into knowledge that which he perceives, to sliape his world. . . . Through Imagination inan lives, an inmate of an active umiverse,

By sensible impressions not enthralled,

But quickened, rouzed, and made thereby more fit

To hold commumion with the invisible world." 
Romantic sense, it is easier to recognize and reward as an "author" one who paints on canvas with inspiration from nature than one who paints on chima with inspiration from old inovie stills. ${ }^{22}$

On the whole, the full-blown Romantic conception of "authorship" has a contmuing grip on the legal imagination. ${ }^{23}$ Subsequent sections of this Article, however, explore how lawyers and judges strategically suppress or revise this traditional concept. And to launch that exploration, the following section outlines the structure of copyright doctrine that the foundational concept of "authorship" supports.

\section{The Structural Dilemma of Copyright Doctrine}

\section{A. The Public/Private Contradiction}

Copyright doctrine is informed by a commonly perceived, seemingly basic contradiction of purpose. On the one hand, copyright aims to pronote public disclosure and dissemination of works of "authorship"; on the other hand, it seeks to confer on the creators the power to restrict or deny distribution of their works. ${ }^{24}$ This conflict is reflected in the tension betwecn public benefit and private reward inscribed in the full title of the first British copyright law, the Statute of Anne of 1709: An Act for the Encouragement of Learning by vesting the Copies of printed Books in the

S. GILl, WILlIAM WordswORTH: A LIFE 239 (1989) (quoting Wordsworth, supra, at 1103-05).

22. The primacy of art and poetry produced by creative artists who draw their inspiration directly from nature was a central tenet of English Roinanticisin. See J. WORDSWORTH, M. JAYE \& R. WOOF, WILliam WordSWORTH AND THE AGE OF ENGLISH ROMANTICISM 87-131 (1987) (discussing the importance of nature to Romantic essayists, novelists, and painters, and noting the common imagery of the artist's mind as an "Aeolien Harp"). I ain indebted to Jane Ginsberg for lier identification of the genealogy of the "Romantic literary commonplace . . . [that characterizes] the 'original' work drawn from nature or experience as a 'copy,' and the imitation of the original as the 'copy of a copy.'" See Ginsberg, supra note 10, at 1882 n.57. It is clear that Judge Posner has accepted this distinction, and its hierarchical implications, at face value.

In one recent discussion of copyright, however, Judge Posner appears to reject the Romantic notion of "authorship" that I argue le implicitly embraces in Gracen. In Law and Literature: $A$ Misunderstood Relation, lie concludes that the "allusiveness" of a T.S. Eliot might be inhibited by broad copyright protection. In that characteristic of Eliot's verse, he continues: "we find a concrete reason for his liostility to the Roinantic movement. To the Roinantic idea of creativity as originality Eliot opposes, and im his poens exemplifies, the older idea of creativity as imitation with enrichment." R. POSNER, supra note 20, at 348-49. That Posner does not practice in Gracen what lie preaches in the just-quoted passage reflects the inability of the law to achieve a stable vision of "authorship."

23. For example, coinputer software copyriglit is often justifled on the grounds that programs are no less inspired than poeins and that the imaginative processes of the programmer is fundamentally akin to that of the literary "autlior." See, e.g., Clapes, Lynch \& Steinberg, Silicon Epics and Binary Bards: Determining the Proper Scope of Copyright Protection for Computer Programs, 34 UCLA L. REV. 1493, 1510-45 (1987).

24. This formulation may not accurately capture the true essence of the fundamental conflict of interests that underlies copyright. 


\section{authors' or Purchasors of such Copies during the Times therein mentioned. ${ }^{25}$}

This tension of goals is useful in analyzing copyright doctrine using the tools of structuralist analysis. ${ }^{26}$ At present, the surface patterning of American copyright law is in apparent disarray. Judges and writers cannot agree on the most basic propositions. ${ }^{27}$ Yet despite this disarray-or perhaps because of it-it is possible to offer a reasonable account of the structure of copyright doctrine as a function of the impossibility of serving one of the described objectives without disserving the other. Many particular doctrinal constructs thus are simply attempts to mediate the basic contradiction between public benefit and private reward. Their instability is guaranteed because the two goals are irreconcilable.

\section{B. Mediation in Copyright Doctrine}

An example of such a construct is the notion that copyright is an incentive to creativity. The United States Supreme Court has adopted this construct as a mediating principle: "Creative work is to be encouraged and rewarded, but private motivation must ultimately serve the cause of promoting [its] broad public availability ...."28 Unfortunately, legislative and judicial attempts to apply this rhetorically-satisfying formula to actual cases immediately confront questions that defy einpirical analysis: How much of a reward is appropriate in exchange for a given amount of public availability? How long should a copyright endure?29 And how intense should copyright protection be if it is to pro-

25. 1709,8 Anne, ch. 21 .

26. For a more complete development, see Jaszi, Fact Works and All That-A (Slightly) Structuralist Overview, in Fundamentals of Intellectual Property Law Practice Before Agencies, Courts aNd IN Corporations 348 (A.B.A. Section of Patent, Trademark and Copyright Law 1987).

27. For example, how should the "originality" that distinguishes a copyrightable work from a non-copyrightable one be measured? How similar must two works be for one to be an infringement of another? To what extent should copyright protect mere compilations of factual materials? To what extent should copyright protect the desigu features of works of "applied art" (i.e., utilitarian products)? When does artistic collaboration result in joint ownership of copyright? And the list goes on!

28. Twentieth Century Music Corp. v. Aiken, 422 U.S. 151, 156 (1975).

29. United States law provides a basic term of copyright extending through the last day of the 50th year following the holder's death. See 17 U.S.C. \$ 302(a) (1988). In seetions 23 and 24 of the 1909 Act, Congress provided an initial 28-year term, which could be extended for an additional 28 years by renewal.

Although the current 50-year standard is probably the most common throughout the world, some national laws provide for less and a few provide for more. See S. RICKETSON, THE BERNE Convention for the Protection of Literary AND ARtistic Works: 1886-1986, at 356-63 (1987). The issue of duration is one that tends to be resolved on an ad hoc basis, taking into account the competing public and private interests. It is unlikely to be scientifically resolved or even the subject of reasoned discussion. Id. at 320-21. 
vide adequate incentive without producing unnecessary restrictions on access? Ultimately, the incentive analysis of copyright succeeds only in reproducing the underlying tension of objectives in new forms.

As Claude Lévi-Strauss pointed out, one method of mediating between conflicting primciples is to replace a pair of starkly contrasting terms with another pair representing what (superficially) appears to be a more reconcilable opposition. ${ }^{30}$ Following this pattern, courts tend to downplay the fundamental contradiction in the goals of the copyright systein by einphasizing the so-called idea/expression dichotomy. Where copyright in a work protects only the latter, leaving the former free for all to use, the tension between the collective interest and that of the individual appears somewhat less acute. ${ }^{31}$ The problem, of course, is that the idea/expression line has proved difficnlt or impossible to draw in practice. ${ }^{32}$ The instability of this distinction is the source of many particular features of contemporary American doctrime that relate to copyrightability and the infringement of copyright. ${ }^{33}$ But the distinction itself is no more than a reflection of an underlying tension of purpose.

30. Lévi-Strauss, The Structural Study of Myth, in Structural ANTHRopology 224 (C. Jacobson \& B. Shoepf trans. 1963).

31. The distinction, now embodied in section 103(a) of the 1976 Copyright Act, became prominent in American copyright jurisprudence in the last quarter of the nineteenth century, although its roots stretch back to the beginnings of copyright. It figured prominently in the Supreme Court's decision in Baker v. Selden, 101 U.S. 99, 103-05 (1879), and in the same year the treatise writer Eaton S. Drone could comfortably and confidently assert:

Literary property ... is not restricted to the one form of language in which thoughts are expressed, but is in the intellectual creation which is embodied in such language. This creation, in whatever language or form of words it can be identified, the "author" may claim as his property. That there can be no property in thoughts, conceptions, ideas, sentiments, \&c., apart froin their association, is clear; for they are then incapable of being identified or owned exclusively. But their arrangement and coinbination in a definite form constitute an intellectual production, a literary composition, which has a distinct being capable of identification and separate ownership, and possessing the essential attributes of property. The property is not in the simple thoughts, ideas, \&c., but in what is produced by their association.

E. Drone, A Treatise on The Law of Property in Intellectual Productions in Great BRITAIN AND THE UNITED STATES 98 (1879).

32. See Nichols v. Universal Pictures Corp., 45 F.2d 119, 121 (2d Cir. 1930) (L. Hand, J.) ("Nobody has ever been able to fix that boundary, and nobody ever can.").

33. The question of where and how to draw the line between "idea" and "expression" is at the center of current debate over the proper scope of copyright proteetion for computer programsmuch of it revolving around the deeision in Whelan Assocs., Inc. v. Jaslow Dental Laboratory, Inc., 797 F.2d 1222 (3d Cir. 1986), cert. denied, 479 U.S. 1031 (1987). Whelan held that protection may extend to a program's "structure, seqnence, and organization." Id. at 1248. For an argument that the case went too far in its definition of "expression,"see Levine, Comment on Bomito Boats FollowUp: The Supreme Court's Likely Rejection of Nonliteral Software Copyright Protection, 6 COMPUTER LAw. 29, 30 (1989); Nimmer, Bernacchi \& Frischling, A Structured Approach to Analyzing the Substantial Similarity of Computer Software in Copyright Infringement Cases, 20 ARIZ. ST. L.J. 625, 638-39 (1988), and defended as having drawn an appropriate line, see Clapes, Lynch, and Steinberg, supra note 23 , at 1540 . 
This structuralist account of copyright doctrine helps only to a point. It allows us to pigeon-hole many of the acknowledged, overt controversies in terins of modes of dichotoinous thinking traceable to the basic contradiction underlying the law of copyright. But it does not go far enough, and fails to advance our understanding of those features of copyright doctrine-such as the soinewhat shopworn principle of "aesthetic non-discrimination," 34 the kaleidoscopic law of "works made for hire," 35 or the curious lore of renewal ${ }^{36}$ - that are not obviously concerned with delimiting the public and private spheres. Moreover, there are important features of the law of copyrightability which cannot be wholly accounted for in terins of the generative instability of the idea/ expression dichotomy, although they do function to mark off the public domain from the private preserves of copyright owners. An exainple is the body of rules under which the copyrightability of derivative works is assessed according to the extent to which they possess the talisinanic quality of "originality." 37

\section{C. "Authorship" in Relation to the Structure of Copyright Doctrine}

What is missing froin this picture of the structure of copyright doctrine is "authorship," precisely because the centrality of that concept is an uncritically accepted notion. Even the stateinent of the basic contradiction with which this Part began assumes "authorship." The whole structure, as I have just described it, is grounded on an uncritical behef in the existencc of a distinct and privileged category of activity, that generates products of special social value, entitling the practitioners (the "authors") to unique rewards. ${ }^{38}$

Fortunately, non-lawyers have already provided many of the tools we need to break the grip of "authorship" by presenting it as a construct rather than a real category. The writings of several critics and cultural

34. See infra text accompanying notes 99-106.

35. See infra text accompanying notes 131-37.

36. See infra text accompanying notes 138-41.

37. See supra text accompanying notes 12-23 and infra text accompanying notes 107-12.

38. The law of personal property does not hold out to potential or actual automobile assembly line workers the possibility of acquiring a stake in the cars they might produce, in addition to a wage, to motivate them to choose this line of work initially or to pursue it thereafter. Yet just such "incentives"-however illusory they may prove-are held out to "authors" by the law of copyright. I am indebted to my colleague James Boyle for this illustration. See Stemer, With a Bang and a Whimper, The Times (London) Literary Supp. Dec. 28, 1990, at 1392, col. 2 (book review of A. KERNAN, THE DEATH OF LITERATURE (1990)):

The death of hiterature was preceded by romanticism and modernism, a time of literary giants in which book culture was supreme. The author then was a being set apart from normal contingencies, receiving special concessions from society, owning copyrights for the Id. words he or she had written, passing the proceeds of writing on to heirs. 
historians recently have illuminated what Martha Woodmansee has called the "economic and legal conditions of the emergence of the 'author.' "39 In suminary, they describe "the appearance in the eighteenth century of copyright laws and the linked artistic ideas like creativity and originality as a conversion of . . . 'things of the mind into transferable articles of property.... [that] has matured simultaneously with the capitalist system." "40

Woodmansee focuses on the early stages of this process and on the origin of the association between "authorship" and genius. In tracing the German reception of the ideas of the English literary theorist Edward Young (whose 1759 Conjectures on Original Composition ${ }^{41}$ also would influence the developinent of Enghish Romanticisin), she notes that "Young preached originality in place of the reigning emphasis on the mastery of rules extrapolated froin classical hiterature, and he located the source of this essential quality in the poet's own genius." 42 One reason the German theorists adopted this vision of "authorship," she suggests, is that "Young's ideas answered the pressing need of writers in Germany to establish ownership of the products of their labor so as to justify legal recognition of that ownership in the form of copyright law."43 Other writers, notably N. N. Feltes, have stressed the alienability of the "author's right[s]," showing how, in the course of the late eigliteenth and nineteenth centuries, the productions of " "professional' author[s]" increasingly took the form of what Feltes terms "cominodity-text[s]," created for the marketplace and subject to its constraints. ${ }^{44}$

This notion of "authorship" has been deployed and transformed in legal discourse and has given rise to important doctrimal structures in the law of copyright. What follows is a brief history of the development of the "authorship" construct and an examination of its relationship to soine of the characteristic features of contemporary copyright doctrime.

39. Woodmansee, supra note 11 , at 425. In addition to Martha Woodmansee's essential article, see C. Davidson, Revolution aNd the Word: THE RiSE OF the Novel iN AMerica (1986), and N. Feltes, Modes of Production of Victorian Novels (1986).

40. A. Kernan, The Death of Literature 123 (1990) (quoting Sutherland, in Plagiarism-A Symposium. The Times (London) Literary Supp., Apr. 9, 1982, at 414, col. 4).

41. E. Young, Conjectures on Original Composition (E. Marley ed. 1918).

42. Woodmansee, supra note 11 , at 430 .

43. Id. She continues by noting that in his writing, Yo1mg "makes a writer's ownership of his work the necessary, and even sufficient condition for earning the honorific title of 'author,' and he makes such ownership contingent upon a work's originality." Id. at 431.

44. N. Feltes, supra note 39 , at 7-8. 


\section{II. "AUthorship" in the EARLy LAW OF COPYright: History AND PREHISTORY}

"Authorship" first entered the domain of law in 1709, with the passage of the first copyright statute, the Enghish Statute of Anne. ${ }^{45}$ While new to law at this time, however, the terminology of "authorship" had already acquired meaning in the realms of hterature and philosophy. These early associations of the "authorship" concept helped to establish its place and ensure its persistence in the copyright doctrine.

Although labelled "An Act for the Encouragement of Learning," the statute was, in fact, promoted primarily by the London-based fraternity of British publishers (then designated "stationers" and "booksellers"). Throughout the previous century, the pubhishers had the book trade comfortably to theinselves as the result of a bargain struck between the Crown and their venerable publishing guild. The Honorable Company of Stationers had received a nuonopoly over pubhishing in exchange for a promise of rigorous self-censorship, including the suppression of treasonous and seditious inaterials. ${ }^{46}$ By the century's end, however, this old order had effectively collapsed, as estabhished pubhishers faced unprecedented conpetition froin doinestic and foreign pirates. Their preferred solution was to solicit legislation that gave the "proprietors" of "copyrights" a right of action against those who trespassed on their hiterary property. The publishers expected, of course, that in most instances, they would be the "proprietors." 47

As the cainpaign for new legislation gained force, however, a problem of legislative draftsinanship remained: How would the new statutory rights get into the hands of the publisher/proprietors? Although the rights could have been awarded to the publishers directly, the chosen solution was to vest the rights imitially in "authors," with the understanding that the pubhisher eventually would assume control. Before and

45. 1709, 8 Anne, ch. 21. The centrality of "authorship" in legal discourse would be reinforced later in the eighteenth century as a result of the Romantic reconceptualization of the creative process. Indeed, the Statute of Anne did not by any means completc the recognition of literary "authors" " proprietary imterests in British law. John Feather argnes that the Copyright Act of 1814 represented the "first statutory recognition of the author as a party in the process of writing and publishing. The principle that the "author" should benefit froin his work was established in 1814, and was never to be seriously challenged." Feather, Publishers and Politicians: The Remaking of the Law of Copyright in Britain 1775-1842, 25 Publishing Hist. 45, $45-46$ (1989).

46. See B. KaPLAN, supra note 10 , at $1-4$.

47. The decline of the Stationer's Company and the concomitant rise of statutory copyright are narrated in B. KAPLAN, supra note 10, and L. PATTERSON, supra note 10; fresh and miportant new details are provided in Feather, The Book Trade in Politics: The Making of the Copyright Act of 1710, 8 Publishing Hist. 19 (1980). The story is usefully summarized in Rose, The Author as Proprietor: Donaldson v. Beeket and the Genealogy of Modern Authorship, 23 REPREsENTATIONS 51 (1988). 
after 1710, publishers typically purchased writers' manuscripts for lumpsum payments; such a purchase included the writer's "right of first pubhcation," and after the statute, it also entailed a transfer of the copyright itself.

Publishers who pressed for legislation to recognize the right of "authors" may have miscalculated where the long-term interests of the book trade lay. Although the vesting of rights in "authors" under the Act of 1710 has been characterized as a mere oversight, ${ }^{48}$ it is clear that the booksellers' short-term goals were well served by the choice. In fact, no other strategy would have allowed them to apply as much rhetorical leverage to back up their novel project of obtaining control over literary texts through the elaboration of portable legal rights in texts as "things." The publishers' approach was particularly apt because in general discourse of the early eighteenth century, "authorship" and "control" already were intimiately associated with aspects of what Ian Watt has termed the "vast complex of interdependent factors denoted by the term 'individualism." "49

Although self-referential use of the term was not common in 1710, inembers of the English profession of letters occasionally had designated themselves as "authors" simce Chaucer's time. Some literary professionals dubbed themselves "authors" to signify their claims "to the vocation of "master-poet." "50 They did so to distinguish themselves from common writers, and to ground claims of prerogative with respect to bodies of literary production..$^{51}$

The concept of "autliorship" and the term "autlior" lad acquired special weight by 1710 througli their association with the theme of "pos-

\section{Consider Alvin Kernan's account:}

Why copyright ended up in the hands of writers instead of publishers is suggested by the petition of a group of booksellers rccorded in the Joumal of the House of Commons (26 Feb. 1706, o.s.) when the matter was being considered; it read in part: "[m]any learned Men have spend much Time, and been at great Charges, in coinposing Books, who used to dispose of their Copies upon valuable Considerations, to be printed by the Publishers ... but of late Years such Properties have been much invaded, by other Persons printing the same Books ...." It seems a hkely inference that while it was the booksellers who were pushing the issue, they were using the author's rights as a blind for their own interests. No one, however, seems to have recognized the radical change of ownership froin printer to writer that had occurred in the statute, and after its passage all went on, as they had before, selling and purchasing what the booksellers and authors still assumed to be perpetual rights in books old and new.

A. Kernan, SAmuel Johnson \& the Impact of Print 99-100 (1989).

49. I. WATt, The Rise of the Novel: Studies in Defoe, Richardson and Fielding 60 (1957).

50. P. Stallybrass \& A. White, The Politics and Poetics of Transgression 123 (1986).

51. See D. RigGs, BeN Jonson: A Life 351-53 (1989). 
sessive individualism" in general social thought. ${ }^{52}$ John Locke's version of individualisin at least implicitly identified the individual's proprietorship over himself as a function of "authorship."53 Thomas Hobbes made the poimt explicitly in his definition of "person":

He whose words or actions are considered either as his own or as representing the words or actions of another man or of any other thing to whom they are attributed, whether truly or by fiction. When they are considered as his own, then is he called a natural person; and when they are considered as representing the words and actions of another, then is he a feigned or artificial person. ... Of persons artificial, some have their words and actions owned by those whom they represent. And then the person in the actor, and he that owns his words and actions is the author; in which case the actor acts by authority. ${ }^{54}$

For Hobbes, the inonarch was the example, par excellence, of the person who was the "author" of his own words.

Significantly, the possibility of vesting the right to prosecute piracies in "authors" may have been raised in the first instance, by Daniel Defoe, in a 1704 paniphlet entitled $A n$ essay on the regulation of the press. ${ }^{5 s}$ Defoe, as Watt has argued, is a figure intimately associated with the ennergent individualisin of the late seventeenth century-his Robinson Crusoe is an avatar of this new vision of man's relationship to society. 56 So by the time that it was deployed in the service of the bookseller's objectives, the vocabulary of "authorship" was, quite hiterally, a vocabulary of "author-ity," 57 and the word "author" was a word of power. Even prior to its adoption as a term of art in intellectual property law and its investment with the associations of Romanticism, the idea of "authorship"-individual control over the created environment-informed the term in the era of pre-imdustrial capitalism.

52. See generally C. MacPherson, The Polmical Theory of Possessive Individualism (1962). MacPherson writes that "original seventeenth-century individualism contained the central difficulty, which lay im its possessive quality. Its possessive quality is found in its conception of the individual as essentially the proprietor of his own person or capacities." Id. at 3.

53. C. DAvidson,supra note 39, at 52 ("Locke... saw every mind as a blank page upon which experience wrote a 'self." ").

54. T. HobBes, Leviathan 23 (H. Schneider ed. 1958), quoted in J. Bender, Imagining the Penitentiary: Fiction and the Architecture of Mind in Eightcenth-Century England 192-93 (1987).

55. Feather, supra note 47, at 29. For an account of efforts undertaken by Defoe during this general period as a spy and polemicist on behalf of Robert Harley, First Earl of Oxford, see generally P. BACKSCheider, DANIEL Defoe: His LIFE 155-200 (1989). It is unclear what role Harley (who had dominated the debate over press control that prefigured the enactment of the Statute of Anne) played in the preparation of this particular pamphlet.

56. See I. WATT, supra note 49 , at $60-80$. He points out that Crusoe exemplifies both "economic individualism," id. at 63, and "Puritan individualisnn," $i d$. at 74.

57. See generally Boyle, The Search for an Author: Shakespeare and the Framers, 37 AM. U.L. REV. 617 (1988). 
The "authorship" construct, although still incoinplete when introduced into English law in 1710, was a charged receptacle, prepared to collect content over the next century. Although the concept of "authorship" was introduced into Englislı law for the functional purpose of protecting the interests of booksellers (and continued to do so throughout the eighteenth century and beyond), ${ }^{58}$ the term took on a life of its own as individualistic notions of creativity, originality, and inspiration were poured into it.

"Authorship" became an ideology. ${ }^{59}$ By the early nineteentli century, its array of connotations and associations was essentially coinplete, and the interests of publishers had disappeared from the public discourse of copyright law. Instead, the fundamental pohicy conflict came to beand continues to be-stated as one between the interests of "authors" and those of "users." As the "authorship" construct accumulated force and circumstantiality, the strategic manner in which the construct initially had been deployed was effaced.

\section{The "Author" Produces the "WORK"60}

Copyright began with "authorship." But as copyright law developed, new terminology served to solidify the notion of literary property. Specifically, a tendency developed to define the "author" reflexively, in terms of the "work" 61 - a term signifying the abstraction that receives physical inanifestation in a particular "copy" or "copies."62 However, the notion of "author" was at least inodestly well-entrenched before the term "work" entered the discourse of hterary property as a significant

58. See Amory, "De facto Copyright"? Fielding's Works in Partnership, 1769-1821, 17 EIGHTEENTH CENTURY STUD. 449 (1984).

59. For general discussions of the ideological function of law, with respect to both its practitioners and its consumers, see Hay, Property, Authority, and the Criminal Law, in ALBlon's FaTAI TREe: CRIMe and SOCIETy IN Elghteenth-Century ENGland 17, 32-39, 52-54 (1975); E. Thompson, Whigs aNd HuNTERs: The ORIGIN OF THE Black ACt 258-69 (1975).

60. M. Foucault, What is an Author?, in Textual Strategies: Perspectives IN PostStruCtURALIST CRITICISM 141 (J. Harari ed. 1979). Foucault discusses the relationship between the "author" and what is termed the "work." Id. at 143. There is, however, a significant distinction to be drawn between this usage of "work," to translate the French "oeuvre," and the legal usage discussed below. Whereas Foucault refers to the body of hiterary production that is organized by its ascription to a particular "author," the legal usage of "work" refers to the individual product, considered in isolation.

61. The Copyright Act of 1976 states: "Copyright protection subsists . . . in original works of authorship ... [and] copyright in a compilation or derivative work extends only to the material contributed by the author of such work." 17 U.S.C. $\S \S 102(a), 103(b)$ (1988).

62. The Copyright Act defines "copies" as "material objects, other than phonorecords, in which a work is fixed by any inethod ...." Id. $\S 101$. 
term in discussions about the reach of the Statute of Anne. ${ }^{63}$ The "authorship" concept, with its roots in notions of individual self-proprietorship, provided the rationale for thinking of literary productions as personal property with various associated attributes including alienability. But the einpliasis on "authorship" left questions about the scope of "authorship" rights unanswered. In effect, "authorship" reproduced the fundamental contradiction betwecn control and access. A stress on the interests of past "authors" could generate arguments for broad copyright protection, while an einpliasis on the interests of future "authors" could generate equally coinpelling arguments for strict limitations on the scope of copyright protection.

\section{A. Free Access, Commodification, and the Rise of the "Work"}

As it turned out, in the first generation after the Statute of Anne, the latter set of arguments prevailed. In a line of early cases concerning adaptations, the scope of copyright law was narrowly limited to protect only the "author's" verbatim text in its original form, ${ }^{64}$ a limitation innposed in the name of "authorship." The statute, after all, inade it an infringement to "print, reprint, or import" a copyrighted book without "authorization," 65 and at the outset the courts treated non-identical imitations as meritorious new productions by new "authors," not as infringeinents. Benjamin Kaplan summarized these decisions: "[W]e can say that the infringement problem was being answered ... by looking not so inuch at what the defendant had taken as to what he had added or contributed." 66

The early adaptation cases bear no resemblance to the results reached in analogous contemporary cases. ${ }^{67}$ The "authorship" contributed by the creator of an unauthorized adaptation no longer can save

63. Discussing the late eighteenth-century dispute over the existence of perpetual, common law copyright, Mark Rose notes that "however approached, the question centered on the same pair of concepts, the 'author' and the 'work,' a person and a thing." Rose, supra note 47, at 63.

64. B. KAPLAN, supra note 10, at 17. These decisions take a definite view of the relative claims of the "original author" and the maker of an abridgement, recognizing that such an abridgeinent can be a meritorious work in itself, and therefore not an infringement of the work abridged. See, e.g., Gyles v. Wilcox, 2 Atk. 141, 26 Eng. Rep. 489 (1740); Barn. Ch. 368, 17 Eng. Rep. 682 (Ch. 1740); Newberry's Case, Lofft 775, 98 Eng. Rep. 913 (Ch. 1773) (discussed in B. KaPLAN, supra note 10, at 10-12).

65. 1709, 8 Anne, ch. 21 .

66. B. KAPLAN, supra note 10 , at 17.

67. See, e.g., Rogers v. Koons, 751 F. Supp. 474 (S.D.N.Y. 1990). Rogers held that the copyright in a photograph was infringed by a three-dimensional sculptural imitation on the ground that the "test of substantial similarity in the Second Circuit is "whether an average lay observer would recognize the alleged copy as having been appropriated from the copyrighted work." "Id. (quoting Ideal Toy Co. v. Fab-Lu Ltd., 360 F.2d 1021, 1022 (2d Cir. 1966)). 
that creator from being deemed an infringer: "No plagiarist can excuse the wrong by showing how much of his work he did not pirate."68 This doctrinal reversal might have come about through the redeployment of the Romanticized concept of "authorship" to justify the protection of every element of an "author's" production. Instead, it followed from the emergence of the "work" concept as a new source of guidance and constraint im copyright, called forth by the inherent instability of the "authorship" construct itself. It would be some time after its first appearance, however, before the "work" would become the vehicle for a significant expansion of copyright protections. First, the new construct had another and more urgent role to play.

The terminology of the "work," denominating a free-standing abstraction as the subject of hiterary property, emerged only im the mideighteenth century ${ }^{69}$ through judicial elaboration of the statutory framework. In the immediate sense, this development was one consequence of the cominercialization and cominodification of print culture that proceeded apace throughout the eighteenth century. ${ }^{70}$ Active commerce in use-rights in hiterary property, separate from physical manuscripts themselves, eventually called forth the new terminology. In effect, the "work"

68. Sheldon v. Metro-Goldwyn Pictures Corp., 81 F.2d 49, 56 (2d Cir. 1936).

69. The designation of an "author's" production as a "work" was current in hiterary circles before the first English copyright law, and carried the connotation of a hiterary production of special value or merit. It also referred to the output of a writer who professed, as Richard Helgerson has phrased it, an "elected vocation" as the laureate:

When they called their poems and plays "works," Daniel and Jonson defined the fundamental pretension of the laureate. (Suckling read this signal aright and in his "Sessions of the Poets" had Jonson tell "them plainly he deserved the bays, /For his were called Works, while others' were but plays.") Amateurs and professionals spoke rather of hiterature-or at least of the literature they wrote-as play. It occupied either the idleness of the writer or the idleness of the spectators.

R. Helgerson, Self-Crowned LaUReates: Spenser, Jonson, Milton and the Literary SYSTEM 39 (1982). However, neither the term "work" nor the concept was in evidence in the prehistory of English copyright. L. Ray Patterson reports that "[i]n the early days of primting, the term 'copy' was used by the stationers to mean what today is called 'copyright,' and it was also used as signifying the manuscript in inuch the same way the term 'copy' is used today." L. PATTERson, supra note 10, at 4. No consistent distinction was made between the abstraction and its physical manifestation because the only possible transaction between a writer and a printer/bookseller was the sale of his "copy"- the physical manuscript and any accompanying use-rights. Even in the Statute of Anne of 1709, which first gave recognition to "authors" " rights, the old terminology of "copy" was preserved.

Benjamin Kaplan has pointed out that the draftsman of the Statute of Anne was still "thinking as a printer would-of a book as a physical entity; of rights in it and offenses against it as related to 'printing and reprinting' the thing itself; of punishment for illicit reprinting as involving in the first instance destruction of the very offending book itself." B. KAPLAN, supra note 10, at 9.

70. See Plumb, The Commercialization of Leisure in Eighteenth-Century England, in THE BirTh of CONSUMER SOCIETY: THE CoMmercialization of EIGHTEENTH-CENTURY ENGLAND 265, 271-73 (McKendrick, Brewer \& Plumb eds. 1982); Rogers, The Commercialization of Eighteenth-Century English Literature, 18 CLIO 171 (1989). 
was the commodity form or objectification of the "author's" labor, and the publisher was able to realize the surplus value of that labor. ${ }^{71}$

\section{B. The "Work" and the Penumbra of "Author's" Rights}

The terminology of early cases reflects an ambiguous attitude towards the nature of the property protected under copyright; eschewing the vocabulary of the "work," they refer instead to rights in "books" and "copies." These terms, especially the latter, could and did refer to interests in plyysical objects or in incorporeal property, or to both sunultaneously. Thus, in an abridgeinent case of 1740, the Lord Chancellor found that the question was "[w]lhetler this book of the New Crown Law, which the defendant has publislied, is the same with Sir Matthew Hale's . . , the copy of which is now the property of the plaintiff," and concluded that " $[w]$ here books are colourably shortened only, they are undoubtedly within the meaning of the act of Parliainent . . ."72 Obviously, the defendant liad not stolen a inanuscript; his wrong consisted of appropriating the plaintiff's intangible hterary property in a so-called "copy." But that term could be used just as well (or better) to describe a physical thing, and its employment here had implications for the court's view of the scope of the plaintiff's rights. Apart froin "colorable" alterations desigued to disguise the identity, the defendant's books had reproduced the entire text as it appeared in the plamtiff's books. It was on this basis that the court found liability; liad the imitation been less complete, the court probably would have ruled differently. The incorporeal property in a "copy" was, so to speak, like the sliadow of the physical text at "high noon"-its sharply defined outline was coextensive with the dimensions of the thing shadowed.

71. Marx, Economic and Philosophic Manuscripts of 1844, in The MARX-Engels ReAder 52, 56-57 (R. Tucker ed. 1972). I am indebted to my colleague James Boyle for pointing out the aptness of the "objectification" analysis to the history of literary property. For a developinent of the notion of the "commodity-text," see N. FelTEs, supra note 39, at 11-14. The developments Feltes describes were, of course, dependent on the prior energence of the "work"-the basic "commodity form" of literary production.

That this new terminology was less than inevitable, however, is indicated by the fact that, as late as 1854, Justice Erle could contribute the following to a House of Lords' decision:

The origin of property is in production. As to works of imagination and reasoning, if not of memory, the author may be said to create, and in all departinents of mind, new books as the product of the labour, skill and capital of the author. The subject of property is the order of words in the author's coinposition; not the words themselves, they are being analogous to the elements of matter, which are not appropriated unless combined, nor the ideas expressed by those words. They exist in the mind alone, which is not capable of appropriation.

Jeffreys v. Boosey, 4 H.L.C. 814,867 (1854). Justice Erle attempts to resolve a central dilemma of copyright doctrine by tracing copyright protections to the "author's" mind, eliding entirely the newer concept of the "work."

72. Gyles v. Wilcox, 2 Atk. 141, 143, 26 Eng. Rep. 489, 490 (Ch. 1740). 
By 1752, however, the new terminology was in place so that the Lord Chancellor could describe a case as posing the issue of "whether the alterations [to the plaintiff's text by the defendant] make [this] a new work, or are intended evasively to colour a new edition."73 In the first edition of Blackstone's Commentaries (1765-69), the concept of the "work" took on soinething of its modern form:

When a man by the exertion of his rational powers has produced an original work, he seems to have clearly a right to dispose of that identical work as he pleases, and any attempt to vary the disposition he has made of it, appears to be an mvasion of that right. Now the identity of a hiterary composition consists intirely in the sentiment and the language; the same conceptions, clothed in the same words, must necessarily be the same composition: and whatever method be taken of exhibiting that composition to the ear or the eye of another, by recital, by writing, or by printing, im any number of copies or at any period of time, it is always the identical work of the author which is so exhibited $\ldots . .^{74}$

Even with Blackstone, the "work" concept was incoinplete. The processes of the objectification of the writer's labor and of her alienation froin that object were not at an end. Nor had the "work" construct developed to the point of becoming, in itself, a mediating term in the tension betwecn ownership and access that is imphicit in a system of hiterary property premised on notions of "authorship." For these developments to occur, the "work" had to develop a truly independent existence, i.e., forcibly separated, so to speak, from the physical inanuscript, of which (even in Blackstone's conccption) it remained inerely the incorporeal shadow.

For the Chancellors whose decisions are quoted above, the central question in higation under the Statute of Anne was whether there was substantial identity between the hiteral language of the volumes in question, and whether any differences between them were merely "colorable" (i.e., inserted to disguise that identity). Before the einergence of the concept of the "work," Blackstone held to the same narrow vision of the scope of copyright: the "work" was still denied an identity wholly independent of the physical manuscript that it shadowed. Gradually, as the notion took hold that the "work" einbraced nore than the hiteral expression enibodied in the corresponding inanuscript, the shadow developed a pronounced penumbra, and the concept of the "work" came fully into its own. For inany purposes, the "work" displaced the "author" as the ccntral idea of copyright law, facilitating the redefinition of the boundary between proprietary control and free public access.

73. Tonson v. Walker, 3 Swans. 671, 678, 36 Eng. Rep. 1017, 1019 (1752).

74. 2 W. Blackstone, COMMENTARIES ON THE LAWS OF ENGLAND $\$ 405-06$. 
The development of the penumbral concept of the "work" can be traced in a series of early nineteenth-century decisions, including Rowarth v. Wilkes. ${ }^{75}$ This 1807 case concerned two books with similar, but not identical, text and illustrations. In the case, Baron Ellenborough stated that the standard for determining infringement was "whether the defendant's publication would serve as a substitute" for the plaintiff's. ${ }^{76}$

In 1822, the Court of King's Bench decided West v. Francis. 77 West involved the reproduction and shight variation of a copyrighted engraving. Ordinarily the special terns of the Engraving Copyright Act ${ }^{78}$ would have governed the case, making the question for decision whether the defendant had copied the "main design" of the plaintiff's "work." Because the plaintiff had invoked special penal provisions, ${ }^{79}$ however, the court's imquiry focused on whether the "work" was a copy of the other. This was the standard inquiry in mainstream copyright infringennent cases involving hiterary "works." Justice Bayley proposed the following standard: "A copy is that which comes so near to the original as to give to every person seeing it the idea created by the original." 80

In the 1835 Exchequer Chainber case of D'Almaine v. Boosey, ${ }^{81}$ counsel for the defendant argued that their chent's musical arrangenent did not infringe on the plaintiff's composition beeause "the defendant's work does not pretend to compete with the elaborate work of the plaintiff's. Their publication is intended for the higher purposes of music, while that of the defendant is adapted entirely and exclusively for dancing." The court's response to this argument signalled the maturation of the penumbral concept of the "work":

[The issue of infringement] must depend on whether the air taken is substantially the same with the original. Now the most unlettered in music can distinguish one song from another, and the mere adaptation of the air, either by changing it to a dance or by transferring it from one instrument to another, does not, even to common apprehensions, alter the original subject. The ear tells you that it is the same. ... Substantially the piracy is where the appropriated music, though adapted to a different purpose from that of the original, inay still be recognized by the ear..$^{82}$

75. 1 Camp. 94, 170 Eng. Rep. 889 (K.B. 1807).

76. Id. at 98,170 Eng. Rep. at 890 (emphasis added).

77. 5 B. \& Ald. 737, 106 Eng. Rep. 1361 (K.B. 1822).

78. 8 Geo. 2 , ch. 13 (1735).

79. Contained in a later enactment, the statute of $17 \mathrm{Geo} .3$, ch. 57 (1777), entitled An Act for more effectually securing the Property of Prints to Inventors and Engravers, by enabling them to sue for and recover Penalties in certain Cases.

80. West, 5 B. \& Ald. at 743, 106 Eng. Rep. at 1363.

81. 1 Y. \& C. Ex. 288, 160 Eng. Rep. 117 (1835).

82. Id. at 302, 160 Eng. Rep. at 123. 
In the United States, a mature concept of the "work" developed later. It was not yet firmly in place in 1853, when a United States Circuit Court considered whether an unauthorized translation of Uncle Tom's Cabin into German constituted an infrimgement of the copyright in the English-language original. Justice Grier rejected the infrimgement claim:

By the publication of Mrs. Stowe's book, the creations of the genius and imagination of the author have become as mucli public property as those of Honier or Cervantes. . . . All her conceptions and inventions may be used and abused by imitators, playwrights and poetasters. [Her absolute dominion and property in the creations of her genius and imagination liave been voluntarily relinquished.] All that now reniains is the copyriglt of her book; the exclusive riglit to print, reprint, and vend it, and those only can be called infringers of her rights, or pirates of her property, who are guilty of printing, publishing, importing or vending with her license, "copies of her book." A translation nuay, in loose phraseology, be called a transcript or copy of lier thoughts or conceptions, but in no correct sense can it be called a copy of her book..$^{83}$

The 1879 edition of Drone on Copyright criticized the somewhat retrogressive holding in Stowe v. Thomas:

The definition that a copy is a literal transcript of the language of the original finds no place in the jurisprudence with which we are concerned. Literary property, as lias been shown, is not in the language alone; but in the matter of which language is merely a means of communication. It is in the substance, and not in the forn alone. That which constitutes the essence and value of a literary composition, which represents the resnlts of the author's labor and learning, may be capable of expression in more than one forn of language different from that of the original .... The translation is not in substance a new work. It is a reproduction in a new forn of an existing one. ${ }^{84}$

Drone's formulation of the law concerning unauthorized translation, and the scope of the "work," ultimately prevailed in the United States as it had in Great Britain. ${ }^{85}$

\section{The Work in Commerce}

The "work" ennerged in two distinct functional contexts. First, the fully-evolved penumbral concept of the "work" was instrumental in

83. Stowe v. Thomas, 23 F. Cas. 201, 208 (C.C.E.D. Pa. 1853) (No. 13,514). The bracketed sentence is interpolated from a report appearing in 2 AM. L. REG. 210.

84. E. DRONE, supra note 31 , at 451-52.

85. Of course, the maturation of the "work" concept created stresses of its own. In effect, that development realized the expansive, rather than the restrictive, implications of "authorship" for the scope of copyright protection, and the tension betwecn control and access was thus reinscribed in the concept of the "work" itself. In the second plase of copyright doctrine, that tension would be reimagined in terms of the distinction between the work's protected "expression" and its unprotected "idea." 
striking a new balance between public access and proprietary ownership-favoring the interests of proprietors. Second, the identification of the autonomous "work" as the subject of copyright proteetion was crucial to the development of the secondary inarket in literary and artistic productions. Practically, rapid cliange in reproduction and distribution technologies called for an abstract concept of the subject of legal protection. ${ }^{86}$ Ideologically, the new empliasis on the "work" minimized the threat to free excliange posed by the notion of an intimate link between the "author" and lier productions. ${ }^{87}$

The two aspeets of the concept of the "work" have functioned together to shape copyright doctrine in general, and its effects on working writers and artists im particular. Overall, the developments just outhined did little to cliange and less to improve the condition of real-life "authors" engaged in the production of copyrightable written material. Before the emergence of the "work," "autliors" typically sold their manuscripts for lump sum payments; afterwards "authors" parted witl rights in their "works" on the same basis or (with increasing frequency) exclianged those rights for a promise of royalties at a contractually-fixed rate. ${ }^{88}$

On the other hand, the maturation of the "work" as a legal concept increased the leverage of publishers and other purchasers of "authors" rights. Once the penumbral concept of the "work" was firmly in place, the purchasers could acquire a general dominion over the imaginative territory of a particular literary or artistic production. Publishers could use this "authority" to exclude froin that territory not only strangers but the very "author" who first delimited it.

86. This process of change may have begun as early as the fifteenth century, with the invention of moveable type. Its pace increased dramatically in the course of the nineteenth century, with such phenomena as the introduction of imexpensive stereotyping and serial publication, and the widespread dramatization of literary works. Photography, inotion pictures, and electronic media represented further developments along similar lines.

87. The strategic suppression of the "author" is also apparent in the tcrminology by which Anglo-American jurisprudence refers to literary and artistic property: "copyright." By contrast, Continental systems designate this domain as "authors' rights." Continental law contains a number of features-including doctrines of "moral rights"-that limit the alienability of literary and artistic property. See Jaszi, A Garland of Reflections on Three International Copyright Topics, 8 CARDozo ARTS \& ENT. L.J. 47, 59-61 (1989). It is interesting to note that in Continental law the distinction between the physical object in which a "work" is embodied and the "work" itself, so crucial to Anglo-American copyright jurisprudence, is sometimes blurred. The outstanding exainple is the provisions commonly found in national laws for artists resale royalties. Under such "droit de suite" legislation, visual artists are entitled to benefit from the appreciation of their canvases, drawings, and sculptures in the art market. See S. RICKETSON, supra note 29, at 410-13.

88. See generally N. CRoss, The Common WRIter LIFE IN Nineteenth-Century Grub STREet (1985); J. SUTHERLAND, Victorian NovelistS AND Publishers (1976). 
That "authors" can infringe upon their own works is illustrated in the case of Gross 1 . Seligman. ${ }^{89}$ This 1914 American decision involved a photographer whose recent picture was found to infringe upon the copyrights in one of his earhier productions. Noting that he had transferred the copyright to a publisher, the court pointed out that its rule was not limited to photographs:

If the copyrighted picture were produced with colours on canvas and were then copyrighted and sold by the artist, he would infringe the purchasers' rights if thereafter the same artist, using the same inodel, repainted the saine picture with only variations of detail and offered it for sale. ${ }^{90}$

The legal conclusion depends, of course, on the mature concept of the "work." In comparing the two photograplis, the court noted that:

The backgrounds are not identical, the model in one case is sedate, in the other smiling; moreover the young woinan was two years older when the later photograph was taken, and some shight changes in the contours of her figure are discoverable. But the identities are much greater than the differences....91

The instrumentality of copyright made possible the legal alienation of an aspect of artistic sensibility (no matter how debased), allowing the singular artist to be subdivided and pluralized:

The identity of the artists and the many close identities of pose, light and sliade, etc. indicate very strongly that the first picture was used to produce the second. Whether the inodel in the second case was posed, and hight and sliade, etc., arranged with a copy of the first plotograph physically present before the artist's eyes, or whetler his mental reproduction of the exact coinbination lie liad already once effected was so clear and vivid that lie did not need the physical reproduction of it, seems to us immaterial. ${ }^{92}$

With the triumph of the expanded concept of the abstract work, the first phase of the history of copyright doctrine came to a close. The process of appropriation that began with the booksellers' unfurling the banner of "authorship" was completed through the legal objectification of the fruits of creative labor. Thus, the necessary conditions for a market in texts as commodities were in place.

Despite these developments, the terminology of "authorship" survived alongside that of the work. In some respects, it is as prominent in contemporary discussions of copyright as it was in the mid-eighteenth century. Although the einergence of the work may have deprived "authorship" of some of its practical importance, it also compounded its

89. 212 F. 930 (2d Cir. 1914).

90. Id. at 931 .

91. Id.

92. Id. 
ideological significance. Karl Marx notes that objectification appears to the laborer as the "loss of the object and object-bondage; appropriation as estrangement, as alienation."93 One ideological function of the "authorship" concept has been to conceal the effects of objectification from the individual creative workers affected by it. ${ }^{94}$

\section{THE "AUTHOR" SURVIVES}

If the story of copyright were tidier, the maturing "work" concept might have induced the demise of "authorship," but this did not occur. Not only did "authorship" take on new ideological importance with the objectification of hiterary and artistic property, but it continued (and contimues) to be strategically deployed to extend copyright protection to new kinds of subject matter. At several crucial junctures in the later developinent of copyright, "authorship" has been imvoked to justify additional legal appropriations of creative (and not-so-creative) efforts.95

In Burrow-Giles Lithographic Co. v. Sarony, ${ }^{96}$ the Supreme Court utilized the "authorship" concept to justify that copyright could constitutionally extend to photographs as "representatives of original intellectual conceptions of the 'author.' "The Court emphasized that a lower court had found the photograph in question to be a:

useful, new, harmonious characteristic and graceful picture, and that the plaintiff made the sanne . . . entirely from his own original mental conception to which he gave visible form by posing [the subject] in front of the camera, selecting and arranging the costume, draperies, and other various accessories in said photograph, arranging the subject so as to present graceful outlines, arranging and disposing the hight and shade, suggesting and evoking the desired expression, and from such disposition, arrangement, or representation, made entirely by plaintiff, he produced the picture in suit. 97

93. Marx, supra note 71 , at 58.

94. A contemporary example of this "ideological" function of the "authorship" concept can be found in the history of the rise and fall of the "auteur theory" in American film studies. This tendency in motion picture criticism emphasizes the authorship claims of motion picture directors and deeinphasizes alternative characterizations of filmmaking as a collaborative art form or an industrial process of commodity production. It gained currency in the United States at the time when the American commercial inotion picture industry was economically rationalized at the expense of what rentained of the relative creative autonomy of individual filmmakers. See Jaszi, Comments in U.S. Copyright OfFice, Technological Alterations to Motion Pictures, Appendix I, at 154, (Mar. 1989).

95. For a discussion of the role of "authorship" in current debates over the copyright status of computer software, see supra note 33.

96. 111 U.S. 53 (1884).

97. Id. at 54-55. Recently, an attempt was made to exploit the rationale of Burrow-Giles, which enuphasized the importance of the photographic subject's pose and personal appearance, to show that a subjeet should be considered a "joint author" of her portrait. The issue arose in a dispute over the propriety of a firm's activities that offered a "cut-rate" photoduphicating services to the clients of 
The passage evokes notions of individualistic artistic genius in a new technological context. The Court's reliance on the Romantic conception of "authorship" was underlined in subsequent passages that reviewed British precedent and concluded that "[t]liese views of the nature of "authorship" and of originality, intellectual creation, and the right to protection confirm what we have already said."98

Even after the maturation of the "work," then, "authorship" still had its uses. Since the mid-nineteenth century, however, the ideologically-charged nature of "authorship," with its aceumulation of association, sonietimes has threatened to disrupt doctrinal developinents in the field of copyright. On these occasions, the concept has been suppressed or revised in the discourse of the subject. A few such instances are highlighted in the following section.

\section{A. The "Author" Vanishes}

The first weeks of almost any basic American copyright course feature two Suprene Court cases: Burrow-Giles Lithographic Co. v. Sarony ${ }^{99}$ and Bleistein v. Donaldson Lithographing Co. ${ }^{100}$ Burrow-Giles involved the copyright of routine studio photograpliy, and Bleistein, decided about twenty years later, concerned the copyright of circus posters. The decisions are presented as two related aspects of the process by which, over the last century, American copyright law has expanded its

studio and school photographers, in direct competition with those photographers themselves. The firm's rationale was that as "joint authors" of photographs depicting themselves, those clients were entitled to authorize the copying of those photographs. The judge hearing the case determined that "[t]he simple fact that an individual brings his own image to the studio is not enough to give that person a protectible interest in the portrait." Olan Mills, Inc. v. Eckerd Drug of Texas, Inc., Copyright L. Rep. (CCH) I 26,420 (N.D. Tex. 1989). Thus, the "authorship" concept is not infinitely expandable, at least where its expansion impinges on the legal independence of the "work."

Jane Gaines has pointed out that the decisions in various early photography cases, including Burrow-Giles itself, likewise suppressed the "authorship" claims of photographic subjects, enphasizing instead the "artistry," "personality," and creative choices of the photographer. See J. GaINES, Contested Culture: The Image, The Voice, and the LaW (1991).

98. Another version of this story is told at length in Bernard Edelman's Ownership of the Image. He begins by recounting early refusals of French courts to extend copyright protection to photographic works, based on the concern that photography represented an essentially mechanical or industrial process and that "[t]he product, the photographic negative, is soulless because only the machine works, and the photographer 'has inerely learned to get it working property ... and to set up chermical operations for reproduction.'" B. EDELMAN, supra note 10, at 45-46. Edelman goes on to argue that, as the nineteenth century progressed, legal protection for photography became a "necessity of industry," and subsequently "the courts utilised the concept of 'imprint of personality" to wrest photography froin the machine and to bring it into the domain of the actuating subject." Id. at 51 .
99. 111 U.S. 53 (1884).

100. 188 U.S. 239 (1903). 
coverage from strictly forms of "fine art" to include "mass" and "commercial" art.

If only the results are considered, the two decisions will bear this conventional interpretation. But if their vocabularies and rhetorical strategies are compared, a dramatic contrast between the two appears. Whereas Burrow-Giles emphasized the "author," with only a general reference to the "work" (as "useful, new, harmomous and graceful"), 101 Bleistein adopted the opposite tactic by focusing primarily on the characteristics of the posters themselves and making numerous references to art works of acknowledged stature:

[E]ven if they had been drawn from the life, that fact would not deprive them of protection. The opposite proposition would mean that a portrait by Velasquez or Whistler was common property ....

These chromohthographs are "pictorial illustrations." The word "illustrations" does not mean that they must illustrate the text of a book, and that the etchings of Rembrandt or Steinla's engraving of the Madonna di San Sisto could not be protected today if any man were able to produce them .... A picture is none the less a picture and none the less a subject of copyright that it is used for an advertisement. And if pictures may be used to advertise soap, or the theatre or monthly magazimes, as they are, they may be used to advertise a circus. Of course, the ballet [which was the subjeet of one of the posters] is as legitnnate a subject for illustration as any other. A rule cannot be laid down that would excommunicate the paintings of Degas.

It would be a dangerous undertaking for persons trained ouly to the law to constitute themselves final judges of the worth of pictorial illustrations, outside of the narrowest and most obvious limits. At one extreme some works of gemus would be sure to miss appreeiation. Their very novelty would make them repulsive until the public had learned the new language in which their "author" spoke. It may be more that doubted, for instance, whether the etchings of Goya or the paintings of Manet would have been sure of protection when seen for the first time ....102

The anonymous artist who labored to publicize, inter alia, the "Stirk family, performing on bicycles, and ... groups of men and women whitened to resemble statues" 103 is not compared to Velasquez, Whistler, Degas, Manet, and company. Rather, the results of his or her efforts are portrayed as standing on an equal footing, work for work, with theirs. Far from emphasizing the importance of "authorship," or conjuring up the elevated connotations that the term had acquired in the Roinantic era, the Court played down the significance of the creator's input: Even

101. 111 U.S. at 60.

102. Bleistein, 188 U.S. at 249-51.

103. Id. at 248 . 
the humblest creative effort is ordinarily protected because "[p]ersonality always contains soinething unique. It expresses its singularity even in handwriting, and a very modest grade of art has in it soinething irreducible, which is one inan's alone." 104

The Bleistein opinion, with its enphasis on the "work" and its abdication of a judicial role as aesthetic arbiter, both effaces and generalizes "authorship," leaving this category with hittle or no meaningful content and none of its traditional associations. ${ }^{105}$ In so doing, the opinion rationalizes a significant expansion of copyright protection. In effect, the revision of "authorship" in Bleistein was instrumental in broadening and generalizing the category of works that could be considered as copyrightable commodities. ${ }^{106}$

The disassociation of "authorship" froin "gernus," and its reassociation with the meanest levels of creative activity, continued apace in copyright cases after Bleistein. Perhaps the most striking example of this tendency is the noted decision in Alfred Bell \& Co. v. Catalda Fine Arts, Inc. ${ }^{107}$ Alfred Bell involved the copyrightability of art reproductions created by the labor-imtensive mezzotint process. The opinion might have einphasized the considerable artistic deinands on the successful mezzotint engraver, but did not. Instead, the circuit court opinion miphicitly rejected the traditional vision of "authorship," beginning with a quotation from the 1894 ease of Henderson v. Tompkins, 108 and continuing on its own terms:

There is a very broad distinction between what is implied in the word 'author,' found in the constitution, and the word 'inventor.' The latter carries an implication which excludes the results of only ordinary skill, while nothing of this is necessarily involved in the former... [A] multitude of books rest safely under copyright which show only ordinary skill and diligence in their preparation...

....

All that is needed to satisfy both the Constitution and the statute is that the 'author' contributed something more than a 'merely trivial'

104. Id. at 250. In light of this passage, the subsequent assertion that the creation of the posters required at least technical skill looks like lagniappe. Id. (quoting J. RUSKIN, ELEMENTS OF DRAWING, Elements of Perspective 3 (1907)).

105. For a contrary interpretation, se B. KAPLAN, supra note 10, at 35 ("Holmes's insistence on individuality or personality ... seems to me to have an echo in it of the Romantic gospel.").

106. One is forcibly reminded here of Bernard Edelman's comment on the European cases that afford copyright protection to mere non-"artistry" documentary photographs: "The over-appropriation of the real is constituted by the simple recording of the real. It is impossible to go further than this." B. EdelmaN, supra note 10, at 67 (einphasis added).

107. 191 F.2d 99 (2d Cir. 1951) (Frank, J.). For a complimentary discussion of the fate of "authorship" in Alfred Bell, see Litman, The Public Domain, 39 EMORY L.J. 965, 1010 (1990).

108. 60 F. 758, 647 (C.C.D. Mass. 1894) (emphasis reproduced as shown in Alfred Bell). The Alfred Bell court noted that the Supreme Court cited Henderson with approval in Bleistein. 
variation, something recognizably 'his own.' Originality in this context 'means little more than a prohibition on actual copying.' No matter low poor artistically the "author's" addition, it is enough if it be his own. ${ }^{109}$

Throughout the opinion, Judge Frank placed quotations marks around "author," and the final sentence of the passage is his characterization of the above-quoted discussion of "authorship" in Bleistein. Judge Frank is pushing Bleistein for all it is worth and more. The extent of his defection from traditional notions of "authorship" becomes apparent later in the opinion:

[E]ven if [the reproductions'] substantial departures froin the paintings were inadvertent, the copyrights would be valid. A copyist's bad eyesight or defective musculature, or a shock caused by clap of thunder, may yield sufficiently distinguishable variations. Having hit upon such a variation unintentionally, the "author" may adopt it as his and copyright it. ${ }^{110}$

The objective test of copyrightability for derivative works proposed here-that they contain "distimguishable variations" from the underlying works on which they are based-is one that focuses attention on the work, rather than on its "author." The nature of any creative investment in the variations is, as a practical inatter, siniply irrelevant to the outcoine, save in one respect: the variations inust be traceable to a human actor; they cannot arise froin inere inechanical mishaps. In this sense, "authorship" still inatters, even in the altered doctrinal setting of $A$ lfred Bell. Fimally, Judge Frank's opinion is paradoxical. In substance, the opinion inarginalizes and trivializes "authorship"; in forn, it continues to acknowledge the centrality of the concept.

Alfred Bell coinpleted the partial transfornation of copyright doctrine that began in Bleistein. This inaneuver secured for nuany modestly aesthetic productions the same advantages of copyright protection afforded to conventional hiterary and artistic works. From a commercial standpoint, these advantages are very significant imdeed. ${ }^{111}$ In one sense, the effacement and revision of "authorship" perforned in these opinions represents a siniple response to economic pressures, which generated denuand for legal regulation of the inarket for new categories of intangible goods. In another sense, these decisions represent the last stage in the coinnercialization of cultural production. Under Alfred Bell's "mini-

109. Alfred Bell, 191 F.2d at $102-03$ (citations and footnotes omitted).

110. Id. at 105.

111. Present copyright law gives the owner a qualified monopoly in the exploitation of the work for the period of the "author's life" and an additional 50 years after his or her death-assuming that the work has an identifiable individual author. If not, the term of protection is 75 years from the date of the work's publication, or 100 years from the date of its creation, whichever is the shortest. 17 U.S.C. § 302(a), (c) (1988). 
malist" and "democratized" vision of "authorship," copyright doctrine offers no sound basis for distinguishing between oil paintings, art reproductions, motion pictures, lamp bases, poems, and inflatable plastic Santa Clauses. ${ }^{112}$

If this were the end of the story about the uses of "authorship" in the formation of copyright doctrine, one might simply conclude that the law has acknowledged the "death of the author," in substance if not in form. Yet, reports of the death of "authorship" in copyright are exaggerated. While "authorship" was suffering the reverses just catalogued, the "author" was alive and well in other areas of copyright law-although sometimes hiving under an assumed identity. Perhaps most remarkably, the Romantic vision of "authorship," along with all its imdividualistic baggage, was, and is, central to the conceptualization of the so-called "work-for-hire" doctrine.

\section{B. The "Author" in Spite of Herself: Works Made for Hire}

Despite a tendency of American law to invoke hiberal individualisin to justify economic structures that frustrate the aspirations of real-life individuals, ${ }^{113}$ it is somewhat surprising to encounter the individualistic Romantic conception of "authorship" deployed to support a regime that disassociates creative workers from a legal interest in their creations: the "work-for-hire" doctrine of American copyright law.114 Where the doctrine applies, the firm or individual who paid to have a work created, rather than the person who created it, is regarded as the "author" for purposes of copyright ownership. ${ }^{115}$

Previous sections of this Article traced how the legal objectification of works of "authorship" contributed to the alienation of creative workers from the products of their labor. When a work is deened to have becn made "for hire," that alienation is formally and legally complete: the "author" of the "work" is the person on whose behalf the "work" was inade, not the individual who created it. In this legal configuration,

112. See Mazer v. Stein, 347 U.S. 201 (1954) (lamp bases); Doran v. Sunset House Distrib. Corp., 197 F. Supp. 940 (S.D. Cal. 1961) (Santa Clauses), aff'd, 304 F.2d 251 (9th Cir. 1962). The Alfred Bell approach to "authorship" has also had significant repercussions in the domain of literature, since it positions editors to assert legal "authority" over texts of which they are not, in the traditional scnse, "authors"- -sometimes to the disadvantage of otlier scliolars. See Holroyd, Copyrights and Wrongs: D.H. Lawrence, The Times (London) Literary Supp., Sept. 3, 1982, at 943.

113. Perhaps the most notable example is the notorious Supreme Court decision in Lochner $v$. New York, 198 U.S. 45 (1905), which struck down state wage and hour laws with the observation that "[t]here is no reasonable ground for interfering with the liberty of persons or the right of free contract, by determining the hours of labor, in the occupation of a baker . . .."

114. The Supreme Court recently considered the doctrine in Community for Creative Non-Violence v. Reid, 490 U.S. 730 (1989).

115. 17 U.S.C. $\$ 201(b)$ (1988). 
the employer's rights do not derive from the employee by an imphed grant or assignment. Rather, those rights are the direct result of the employer's status. ${ }^{116}$ Ironically, the eniployers' claims are rationalized in terms of the Romantic conception of "authorship" with its concomitant values of "originality" and "imspiration."

The identification of an employer as "author" is not a particularly venerable idea im Anglo-American copyright. Not so long ago, the Romantic conception of "authorship" appeared to cut against the recognition of a work-for-hire doctrime. This was true at least as late as 1883, when the judges of the English Court of Queen's Bench roundly rejected the notion in Nottage v. Jackson. ${ }^{117}$ The plaintiffs were proprietors of a large photographic studio, and the pictures at issue (of a visiting Austrahan cricket team) had been taken by the studio's photographic artists ${ }^{118}$ at the instigation of a managerial employee. The court rejected the plaintiffs' claim because they were not the "authors" of the pictures. Justice Brett, the Master of the Rolls, expressed his views somewhat dyspeptically:

I confess I have the greatest difficulty in construing this Act of Parliament. Persons who draw Acts of Parliament will sometimes use phrases that nobody else uses.... It says- - The autlior, and so on -of every original paimting." Who ever, in ordinary life, talks of the "author" of a painting?

[N]ow we have "the autlior" of a photograpl. I slould like to know whether the person who drew this Act of Parliament was clear in his mind as to who can be the "author" of a photograph .... [The plaintiffs] think that they are the authors of the photograph because the pliotograpl is inade and formed by the work of their inere servants .... They may live 200 miles off. Can they be called the authors of a photograph of which they know nothing? It is done by their servants. They may go to the shop once a week; and when they are there they inay superintend the operations, though I suppose they very seldoin do .... Take this very case. It is not pretended that the'se gentlemen were at the Oval; they were either in London or fifty miles perhaps the other side of London . . . . I confess I cannot be very clear about it, all I can do is see who is the nearest person-the nearest like the author of a painting or the author of a drawing. Certainly it is not the man who simply gives the idea of a picture, because the proprietor may say, "Go and draw that lady with a dog at lier feet, and in one hand holding a flower." He inay have tlie idea, but still he is not there. He may be 100 miles from the place, and he inay have given the instructions by letter....119

116. Id.

117. [1883] 11 Q.B. 627 .

118. Id. at 627-28.

119. Id. at 630-32. In a similar vein, Lord Justice Bowen stated: 
Lord Justice Cotton stated that " 'author' involves originating, making, producing, as the inventive or master mind, the thing, which is to be protected.... [Here the plaintiffs] did not give the direction or inake the suggestion; but even that, in my opinion, would not do."120 In the reference to the "Inaster mind," this passage contains the germ of a rationale for treating the employer as "author." Yet Justice Cotton seems to have been unconscious of the implications of his language. Like Justice Brett, he was committed to an individualistic, essentially Romantic vision of "authorship" that appeared to exclude such a possibility. American law, however, was about to put a reverse-twist on individualistic "authorship," and the Romantic conception of originality would again be pressed into the service of cominerce.

Before 1909, American copyright statutes did not address the issue of einployed autlors, and courts dealt with it on an ad hoc basis. Some of the earhest decisions, although rewarding the contested rights to the einployer, suggested that the issue should be viewed in contractual terms: "If a patron gives a commission to an artist, there appears to me a very strong implication that the work of art commissioned is to belong unreservedly and without limitation to the patron."121 The Supreine Court in Bleistein held that because the three circus posters were "prepared by einployees of the plaintiffs" there was sufficient evidence of the plaintiffs' ownership-although not hiterally of their "authorship."122

In the deliberations leading up to the Copyright Act of 1909, which first included language stating that the employer was the "author" in the case of "works made for hire," there was no substantive discussion of this definitional innovation, ${ }^{123}$ even on the part of the representatives of various authors' organizations who testified on the new legislation. The legislative treatinent of einployed "authors" in the 1909 Act inight have

Who would have been the author supposing Messrs. Nottage \& Kennard had never been born and that the artists who were employed by them went down on their own business and on their own pecuniary resources to take this picture? Of course the authors would be the artists who took the pictures. Do they become less the authors because they were employed by Messrs. Nottage \& Kennard?

Id. at 632 .

120. Id. at 635 .

121. Dielman v. White, 102 F. 892,894 (C.C.D. Mass. 1900).

122. One may speculate that the wariness of the Supreme Court's approach to the issues of "authorship" in Bleistein, and its complimentary emphasis on the characteristics of the "works" as such, may have been influenced by the implicit ambiguity as to the legal "author's" identity.

In contrast, see Yeungling v. Schile, 12 F. 97 (C.C.S.D.N.Y. 1882), in which an American firm's efforts to assert copyright in a "chromo" executed by a German artist were rebuffed, on the ground that neither the firm (which is not the "author") nor the artist (who is not a citizen) was entitled to protection.

123. See Vanner, Works Made for Hire and on Commission (Study No. 13), in CopYright Law Revision, Studies prepared for the Senate Judiciary Subcomm. on Patents, TradeMARKS AND Copyrights, 86th Cong., 2d Sess. 123, 128 (Comm. Print 1960). 
been seen as a controversial innovation, coming as it did only a few years after the initial, tentative judicial suggestions of a doctrine of "works made for hire." In fact, this aspect of the legislation apparently seemed too insignificant to merit cominent, let alone to occasion protest. That such a superficially radical departure did not attract more attention suggests that, at a deeper level, it was no departure at all, and that there existed some principle of harmony between it and the basic ideological structures of copyright law. Decisions applying the new doctrine would reveal how the "work-for-hire" doctrine could be rooted in a versionalbeit a curiously distorted one-of the Romantic conception of "authorship."

Most early decisions interpreting and applying the work-for-hire doctrine were opaque in their reasoiring, ${ }^{124}$ but by the time Ann Ronnell forced the issue with Walt Disney and Irving Berlin, Inc., over rights to her arrangement of "Who's Afraid of the Big Bad Wolf," things were clear enough. In 1933, the free-lance inusical arranger had been commissioned to help adapt the soundtrack version of "Who's Afraid of the Big Bad Wolf" as a popular song, which she did by "rearranging the inusical theines in collaboration with an employee of Berlin, and arranging the existing lyrics and adding new ones of her own." 125 Twenty-eight years later, she registered a renewal copyright in the song she had helped produce, claiming to be a "joint author." For the Second Circuit Court of Appeals, however, Ronnell was a inere "einployee for hire," and thus not entitled to renew; the renewal belonged imstead to the assignee of her "einployer":

[E]mployees of Berlin did in fact make some revisions in Miss Ronnell's work. Moreover since Disney had control of the original song on which Miss Ronnell's work was based, Disney (and Berlin, with Disney's permission), at all times had the right "to direct and supervise" Miss Ronnell's work.

In short, the "motivating factors" in the composition of the new song ... were Disney and Berlin. They controlled the original song, they took the initiative in engaging Miss Ronnell to adapt it, and they had the power to accept, reject, or modify her work. ${ }^{126}$

The characteristics of the enployer-einployee relationship that Justices Brett and Cotton found irrelevant to "authorship" in 1883 were determinative in 1972. Regardless of who produced the original arrangeinent, it was the individual or firm who could claim "authorship" to the

124. See National Cloak \& Suit Co. v. Kaufman, 189 F. 215 (C.C.M.D. Pa. 1911).

125. Picture Music, Inc. v. Bourne, Inc., 457 F.2d 1213, 1214 (2d. Cir.), cert. denied, 409 U.S. 997 (1972).

126. Id. at 1216. 
work's initiating "Inotivating factor" and inspiration.127 In effect, the visionary component of Romantic "authorship" was disaggregated from the associated component of intellectual and physical labor. The employer was cast as the visionary, and the employee as a mere mechanic following orders. Perverse as this variation on the conventional logic of "authorship" may appear, it is not truly surprising in hight of what had gone before.

In 1989, the Supreine Court confirmed the Roinantic underpinnings of the American "work-for-hire doctrine," as it is specified in new provisions of the 1976 Copyright Act designed to limit the circumstances under which an mdependent contractor or commissioned artist (like Ann Ronnell) would be denied "authorship" of her own works. Indeed, the definition of a work made for hire in section 101 of the Act limited the circunistances when the productions of "freclancers" could be considered works made for hire; specifically, when an exphicit agreement to this effect and the work in question fell into one of nine designated statutory categories. ${ }^{128}$

Despite this statutory langnage, however, several courts thereafter held under some circumstances a commissioned work could be regarded as a "work made for hire" although it did not satisfy the criteria just outlined, as long as it could be characterized as "a work prepared by an employee within the scope of her or her employment"; ${ }^{129}$ this characterization, im turn, would be appropriate when the commissioning party had enjoyed "control" over the creation of the work. ${ }^{130}$

The Supreme Court's approach to this dilemma in Community for Creative Non-Violence v. Reid ${ }^{131}$ was, at best, semi-Solomonic. The

127. The employer's contribution of capital is also a factor in the analysis of many "work-forhire" cases. The typical case, however, tends to deemphasize the employer's economic contributions, and emphasize the "creative" ones. The capital investment is not in any way essential to the determination of whether a particular employer should be considered an "author." The facts of Picture Music suggest that Miss Ronnell received only a promise of future royalties in comeetion with her work for Disney and Berlin.

128. 17 U.S.C. $\S 101$ (1988) (definition of "work made for hire). The categories are "a contribution to a collective work, ... a part of a inotion picture or other audiovisual work, . . a translation, $\ldots$ a supplementary work, $\ldots$ a compilation, $\ldots$ an instructional text, ... answer material for a test, ... [and] an atlas." Id. The legislative history of this provision is exhaustively reviewed in Hardy, Copyright Law's Concept of Employment-What Congress Really Intended, 35 J. CoPYRIGHT Soc'Y U.S.A. 210 (1988).

129. 17 U.S.C. $\$ 101$ (1988).

130. These decisions included Aldon Accessories, Ltd. v. Speigel, Inc., 738 F.2d 548 (2d Cir.) (commissioned work is work of "employec" when commissionimg party exercises "actual" supervision and control), cert. denied, 469 U.S. 982 (1984) ; Easter Seal Soc'y v. Playboy Enters., 815 F.2d 323 (5th Cir. 1987) (potential supervision and control by commissioning party sufficient), cert. denied, 485 U.S. 981 (1988)

131. 490 U.S. 730 (1989). 
unanimous Court concluded that ordinarily the terms of the statute should govern and only specific categories of commissioned works should be considered works for hire. ${ }^{132}$ But an exception to this generalization was applicable when the commissioned artist or independent contractor could be considered the agent of the commissioning party. ${ }^{133}$ The artist in this case is the, einployee, and the commissioning party the employer and "autlior" of the work-regardless of the specific character of the work. ${ }^{134}$

A central question in agency doctrime is whether a hired individual is the servant of the hiring party for a particular function or activity. ${ }^{135}$ According to the Court's formula, the crucial inquiry is "the liring party's riglit to control the manner and means by which the product is accomplislied."136 In Reid, the Supreine Court identified circuinstances supporting the conclusion that the commissioned artist was the "author" of his own sculpture. ${ }^{137}$ The outcoine should not obscure the fact that the standard employed was one whicl can, and often will, deprive creative workers of the "authorship" designation. But it should coine as no surprise that the particular version of the "autliorship" construct emphasized in the "work-for-hire" cases may, in practice, be inimical to the concrete pecuniary and moral interests of writers, pliotographers, sculptors, and otlier flesli-and-blood creative workers. In Reid and the cases leading up to it, certain attributes of Roinantic "autliorship" are emphasized while others are marginalized. If the essence of the Roinantic account of "autliorship" was to be found in its einpliasis on the inspired individual, the profoundly anti-individualistic work-for-hire cases focus

132. Id. at 750 .

133. Id. at 751.

134. The Court drew heavily on the analysis of the case provided below by the United States Court of Appeals for the District of Columbia Circuit. See Community for Creative Non-Violence v. Reid, 846 F.2d 1485 (D.C. Cir. 1988).

135. See Restatement of Agency §§ 2, 220-227 (1933).

136. Reid, 490 U.S. at 751.

137. Id. at 751-52. Although the sculptor in Reid was significantly influenced in the execution of the commission, the Court found that he was not an agent because "all the other circnmstances weigh[ed] heavily against finding an employment relationship." Id. at 752. Previously, the opinion noted:

Among the other factors relevant to this inquiry are the skill required; the source of the instrumentalities and tools; the location of the work; the duration of the relationship between the parties, whether the hiring party had the right to assign additional projects to the hired party; the extent of the hired party's discretion over when and how long to work; the method of payment; the hired party's role in hiring and paying assistants; whether the work is part of the regular business of the hiring party; whether the hiring party is in business; the provision of employee benefits; and the tax treatment of the hired party.

Id. at 751-52 (citations omitted). But if the ultimate goal of the inquiry is to determine "the hiring party's right to control the manner and means by the product is accomplished," however, it is difficult to see how it can also be true that "the extent of control the hiring party exercises over the details of the product is not dispositive." Id. at 752. 
exclusively on inspiration itself. The origins of the "authorship" construct may lie in the tradition of "possessive individualism," but in this version, it serves inerely to rationalize possession.

\section{The STORIES THUS FAR}

To this point, I have shown some (although far froin all) of the vicissitudes to which the concept of "authorship" lias been subject in the nearly 300 years of Anglo-American copyright history: how it was decentered by the rival concept of the "work"; how it was resuscitated in the early plotography cases and suppressed in the later jurisprudence of copyrightability; and finally, how it has undergone a bizarre, inverted revival in law relating to works inade for hire. Although I presented these episodes in roughly chronological order, inost of the developinents illustrated oceurred in substantial synchronicity. I do not suggest that the intensity of belief in "authorship" has waxed and waned with time; rather, I point out that thinking about "authorship" has developed differently, and sonietimes contradictorily, within the subdoinains of copyright doctrine. Soinetimes wildly contrasting attitudes towards "authorship" can and do coexist in legal consciousness.

If this were the whole story, one might interpret these inconsistencies as a logical result of the fundamental contradiction between private control and public access that underlies the institution of copyright. ${ }^{138}$ In this sense, all of these developinents in thinking about "authorship"

138. In capitalist economies, one function of the market is to assure the public distribution of commodities, but the discipline of the market extends to the private attributes of individuals (personality, emotion, sexuality, artistic self-expression) only to the extent that these can be effectively "commodified." And what all the invocations, revisions, and perversions of "authorship" described so far arguably have in common is their instrumental relationship to the process of "commodification" of self-expression.

Yet another example of this tendency may be found in the line of recent cases which, in effect, extend copyright protection to the characteristics of literary or visual "style." Although it is a traditional truism of copyright that "style" is unprotectible, a number of recent decisions applying the "total concept and fecl" standard for assessing substantial similarity indicate that this basic principle may sometimes be honored more in the breach than in the observance. See, e.g., Ronlo v. Russ Berrie \& Co., Inc., 886 F.2d 931 (7th Cir. 1989) (upholding finding of infringement and award of $\$ 4.3$ million on ground that defendants line of greeting cards infringed plaintiff's generally similar group of cards); Sid \& Marty Krofft Television Prods., Inc. v. McDonald's Corp., 562 F.2d 1157, 1166 (9th Cir. 1977); C. Blore \& D. Richman, Inc. v. 20/20 Advertising, 674 F. Supp. 671 (D. Minn. 1987), (defendants sought summary judgment in a suit involving two non-competitive television advertising campaigns featuring the same actress, where plaintiffs had alleged similarities "in regard to editing, change of lairstyle, framing, collar position on blouse and use of a striped blouse, jewelry, tone of voice, raising of eyebrows and voice level"); and Worlds of Wonder, Inc. v. Vector Int'l, Inc., 653 F. Supp. 135 (N.D. Ohio 1986) (rights in an aminated toy bear activated by a specially encoded cassette tape were infringed by defendant's compatible "software"). The connection between this expansive vision of the scope of copyright protection is made explicit in Shaw v. Lindheim, 908 F.2d 531 (9th $\mathrm{Cir}$. 1990), where the appellate court reversed a grant of summary judgment against a 
represent means to the same end-promoting the legal security of firms and individuals engaged in the commercial distribution of creative productions, who act as middlemen between private creators and public consumers. ${ }^{139}$ Indeed, this interpretation accounts for such seemingly contradictory phenomena as the glorification of "authorship" in BurrowGiles, its suppression in Bleistein and Alfred Bell, and its peculiar revival in the work-for-hire cases. Functionally considered, "authorship" has played a role in mediating the conflicting interests at the heart of copyright, and many of the transformations of the "authorship" coneept can be explained in terms of the demands of that role.

But there are significant recent developments in the law of copyright which suggest that the conundrum of "authorship" is not so easily solved. These developments demonstrate that functionalist explanations cannot adequately account for law's recursive insistence that "authorship" is more than a cultural and economic construct and that the Romantic concept of "authorship" does correspond, in fact, to an aspect of social "reality." Judge Posner's opimion in Gracen v. Bradford Exchange ${ }^{140}$ represents one such anomalous recrudescence of Romantic "authorship." The Umited States Supreme Court's recent decision in Stewart $v$. Abend ${ }^{141}$ represents another, and the recent upsurge of "moral rights" in American copyright law yet one more.

\section{A. Copyright Renewal and Reversion}

The issue in Stewart, which involved the legal relationship between underlymg hiterary works and derivative motion pictures, was not a new one. In fact, it was before the Court precisely because the Ninth Circuit's decision below ${ }^{142}$ conflicted directly with an earkier Second Circuit

plaintiff who claimed that the protected expression of his television script, entitled "The Equalizer," was infringed by defendant's television series, which had admittedly borrowed the unprotectible title:

What remains is a subjective assessment of the "concept and feel" of two works of literature-a task no more suitable for a judge than for a jury. This subjective assessment is not a legal conclusion; rather it involves the audience in an interactive process with the author of the work in question, and call on us "to transfer from our inward nature a huinan interest and a semblance of truth sufficient to procure for these shadows of imagination that willing suspension of disbehief for the moment, which constitutes poetic faith."

Id. at 538 (quoting S. Coleridge, BIOGRAPHICA LITERARIA, ch. 14).

139. Copyright is often rationalized in terms of its inportance as an incentive, but it is not always clear what behavior it is designed to incite. It has been suggested that the legal seeurity afforded by copyright may do far more to encourage the commercial distribution of copyrighted works than to stimulate their creation. See generally A. PLANT, THE NEw COMMERCE IN IDEAS AND INTEllectual Property 13-16 (1953) (arguing that copyright is an efficient way to encourage financial investment in the distribution of works to the public).

140. 698 F.2d 300 (7th Cir. 1983).

141. 110 S. Ct. 1750 (1990).

142. Abend v. MCA, Inc., 863 F.2d 1465 (9th Cir. 1988). 
decision, Rohauer v. Killiam Shows, Inc. ${ }^{143}$ Both cases interpreted the provisions of the 1909 Copyright Act. In each case, the writer of a literary work granted the motion picture rights to a producer, purporting to cover both the original and renewal terms of copyright in his or her novel or story. In each case, the producer made and copyrighted a film inaking use of protected material from the literary work. Botli writers died before the renewal copyrights were vested in their literary works, and the designated statutory successors claimed those rights in accordance with section twenty-four of the 1909 Act. Both plaintiffs relied on those rights to bring suit against the present copyright owner of the derivative motion picture, claiming that contmued exhibition and/or broadcast of the films constituted a violation of the renewal copyright in the underlying literary work. ${ }^{144}$

Although the two cases involved different movies-the silent Rudolph Valentino vehicle Son of the Sheik in Rohauer ${ }^{145}$ and Alfred Hitchcock's Rear Window in Stewart ${ }^{146}$-the courts in both cases posed the same issues: How did renewal by a statutory successor, which nullifies any prospective effect of an assignment of rights given by a deceased writer, ${ }^{147}$ affect the status of a motion picture created while the assignment was still in effect? The Courts of Appeals in the two cases reasoned differently. The Second Circuit found that the continued use of the authorized derivative inotion picture did not infringe the renewal copyright in the underlying novel by Edith Hull; ${ }^{148}$ the Ninth Circuit decided that continued use of the film did infringe the rights of the purchaser of the renewal copyright in the Cornell Woolrich short story. ${ }^{149}$

In effect, the conflict that the Supreme Court sought to resolve concerned the extent that an "authorized" derivative work ouglit to be entitled to "independence from the work upon which it was based." 150 In a six to three decision, the Supreme Court sided with the Nintli Circuit-

143. 551 F.2d 484, (2d Cir.) cert. denied, 431 U.S. 949 (1977).

144. For a more complete description of the problem posed by this group of cases, see Jaszi, supra note 11.

145. 551 F.2d at 486.

146. $110 \mathrm{~S}$. Ct. at $1755-56$.

147. See Miller Music Corp. v. Charles N. Daniels, Inc., 362 U.S. 373 (1960).

148. Rohauer, 551 F.2d at 494.

149. Abend, 863 F.2d at 1482.

150. Stewart, $110 \mathrm{~S}$. Ct. at 1774. (Stevens, J., dissenting). Despite this characterization, the case may be better described as raising the question of whether such derivative works should be afforded "limited independence." Even before the decision in Stewart, no one would have contended that the proprietor of an authorized derivative work was entitled to license others to use the incorporated portions of an underlying work, and it never was in doubt that the statutory successor to the renewal copyright in an underlying novel had the authority to forbid "re-makes" of a derivative movie authorized by his or her predecessor. In Stewart, the precise question was whether authorized, copyrighted derivative works are legally distinct from the underlying works on which they are based to 
against the right to free utilization of derivative motion pictures by their copyright owners. ${ }^{151}$ In so deciding, the majority effectively embraced the traditional, Romantic vision of "authorship," with its corollary emphasis on the importance of originality.

Although the opinions in Stewart take the form of an arcane debate about the language and legislative history of some relatively obscure provisions of the Copyright Act of 1909 (principally sections three and seven), in substance they represent a clash of two profoundly different visions of the significance of "authorship." One vision recognizes the equal claims of all creators to legal and non-legal recogintion. It implicitly calls into question the high Romantic conviction that the essence of true "authorship" resides in a privileged connection between the inspired imdividual and the world of natural phenomena. ${ }^{152}$

the extent-and only to the extent-that they might continue to be used after the grants on the basis of which they first were created have been cut off by the operation of renewal.

151. Among the many aspects of Justice O'Connor's decision that merit critical discussion is its discovery that termination of transfer provisions of the 1976 Copyright Act "tilt against petitioners' theory." Id. Section 304(c)(G)(A) of the 1976 Act, like section 203(b)(1), provides for the continued "utilization" after termination of derivative works prepared "under authority of the grant" before termination. In Rohauer, Judge Friendly concluded that although these statutory exceptions did not directly bear on the interpretation of the 1909 Act's renewal provisions, they did indicate the general reasonableness of his reading of those provisions-which likewise favored the owner of a derivative motion picture over one who had "recaptured" rights in an underlying work. 551 F.2d at 493. Justice O'Connor, by contrast, found in section $304(\mathrm{c})(6)(A)$ an indication that "Congress assumed that the owner of the pre-existing work possessed the right to sue for infringennent even after incorporation of the pre-existing work in the derivative work." Stewart, $110 \mathrm{~S}$. Ct. at 1763. The basis of this insight is undermined somewhat, however, by the Justice's acceptance of Jessica Litnan's conclusion that "there is no evidence of what members of Congress beheved the languagc to mean." Id. (quoting Litman, Copyright, Compromise, and Legislative History, 72 CORNELl L. REV. 857, 868 (1987) (footnote omitted)).

Another debatable feature of the opmion is its rather summary disnrissal of the defense of "fair use," premised on the notion that beenuse the defendant's use was "coinmercial" it was presumptively unfair, and rounded out by the adoption of the Court of Appeals' conclusion that the "rerelease of the film inninged on the ability to market a new version of the story." Id. This analysis may ignore the fact that any present market for adaptation rights in the relatively obscure short story It Had to Be Murder is probably a function of the continuing artistic and commercial success of Rear Window as a inotion picture. See id. at 1777 n.18 (Stevens, J., dissenting) (citing Weinreb, Fair's Fair: A Comment on the Fair Use Doctrine, 103 HARv. L. Rev. 1137, 1147 (1990)).

152. An indication of the extent to which Justice Stevens' dissenting opimion "demystifies" the concept of "authorship" is his acknowledgment that the desiguation "author" is, in itself, a commodity in the inarketplace:

A putative author may sell his work to a motion picture company who will have greater use for it, by beconing an employec and making the work "for hire." The 1909 Act gave the employer the right to renew the copyright in such circuunstances.... The Court today holds, however, that the independent entrepreneur, who does not also go into the coinpany's employ and who intends to make independent use of his work, does not also have the same right to sell his consent to produce a derivative work that can be distributed and publicly perforined during the full tern of its copyright protection. That result is perverse and cannot have been what Congress intended.

Id. at 1777-78. 
By contrast, the other vision derives directly from the traditional Romantic orthodoxy and elevates the interests of the creator of the original work and her successors over those of artists who devise subsequent, merely derivative works. In this vision, the ultimate solution to the dilemma posed in Stewart is found in the "axiomatic" and "well-estabhished" 153 principle that only "[t]he aspects of a derivative work added by the derivative author are that author's property ..." because "[t]he copyright is limited to those aspects of the work-terned 'expression'-that bear the stamp of the author's originality." 154 In Stewart, the traditionalist vision triumphs. ${ }^{155}$ In effect, artists who work directly from personal experience, in proximity to the natural raw materials of the creative process, are given a legal preference over those who merely rework prior art-no matter how ably. ${ }^{156}$

Stewart, like Gracen v. Bradford Exchange, ${ }^{157}$ demonstrates the continumg sway exercised in the shaping of copyright doctrine by "authorship" as an autonomous ideological construct. Invocations of "authorship" in other contexts, including the law of copyrightability and the work-for-hire doctrine, can be understood as maneuvers designed to justify the alienation of the creative worker from her work product and the entitlement of others to benefit from its exploitation. But this sort of functionalist explanation does not account for the Stewart majority's naive faith in Romantic "authorship." Motion picture producers and distributors-the commercial "middlemen" of the film industry-can only be disserved by a rule which makes it more difficult and expensive for them to exploit their motion picture "properties." Nor does the general public benefit from a rule which may limit access to films caught in the legal cross-fire between underlying and derivative copyright owners.

153. Id. at 1761. These characterizations are quoted, respectively, from 1 M. NIMMER \& D. NimMER, NimMER ON COPYRIGHT $\S 3.07$ [A], at 324 (1989), and Russell v. Price, 612 F.2d 1123, 1128 (9th Cir. 1979).

154. Stewart, 110 S. Ct. at 1761 (quoting Harper \& Row Publishers, Inc. v. Nation Enters., 471 U.S. 539, 547 (1985)).

155. In Stewart, as in Rohauer before it, the renewal claimant who had succeeded the original author as copyright owner transferred his interest in the renewal copyright, for consideration, to the actual plaintiff. It is some indication of the intensity of the Stewart majority's dedication to the Romantic vision of "authorship" that in the doctrinal world of that decision the "charge" generated by true "authorship" can still be felt at such a distance from the source.

156. This is reflected in Justice O'Connor's comment that "[w]hile the result in Rohauer might make some sense in soine contexts, it makes no sense in others. In the case of a condensed book, for example, the contribution by the derivative author inay be little, while the contribution by the original author is great." Id. at 1763. Here, it is interesting to contrast the British adaptation cases decided in the first generations after the Statute of Anne, before the full fiowering of Romantic "authorship" and the elaboration of the concept of the "work" in copyright. See supra text accompanying note 72 ; B. KAPLAN, supra note 10 , at 10.

157. 698 F.2d 300 (1983). 
Rather, the decision represents the triumph of ideology over concrete economic and cultural interests. Finally, it should be noted that the Stewart rule contributes nothing to the welfare of working artists and writers, as distinct froin vindicating "authorship" in the abstract. 158

\section{B. Romantic "Authorship" Revisited: The Case of Moral Rights}

Creative workers inay be better served by the developinents which evidence another trend rooted in the traditional ideology of "authorship": the upwelling of enthusiasm in the noral rights of "authors," a notion well entrenched in Contmental legal systems but never (until recently) inuch imitated or admired in this country. The particular set of moral rights of "authors" consists of the right to control the circumstances in which the work will be released to the public (the French "droit de divulgation"), the right to withdraw the work from circulation, the right to claim of attribution (the so-called "paternity right"), and the right to object to the distortion or mutilation of the work (the so-called "integrity right"). These inoral rights are retained by the creator of a work even after she has parted with the economic interest in a product. ${ }^{159}$ Recognition of these rights in American law has been recominended as the appropriate solvent for a wide range of the legal/cultural dilemmas in copyright, mcluding over-enthusiastic art conservation, ${ }^{160}$ careless or meretricious editing, ${ }^{161}$ undesired "colorization" of black and

158. Indeed, the result in Stewart las only negative practical implications for the condition of creative workers. Motion picture companies and other purchasers of grants of rights to prepare derivative works will necessarily tend to discount the prices they are willing to pay to the copyright owners of works subject to renewal, to reflect the irreducible uncertainty as to the future value of sucli grants that the Stewart rule creates. As Judge Henry Friendly pointed out in Rohauer, no truly effective way exists for the purchaser of derivative riglits "to protect himself aganist the eventuality of the author's death before the renewal period since there is no way of telling who will be the surviving widow, children or next of kin or the executor until that date arrives." 551 F.2d at 493, quoted in Stewart, 110 S. Ct. at 1778 n.22 (Stevens, J., dissenting). See also Allen \& Swift, Shattering Copyright Law: Will James Stewart's Rear Window Become a Pain in the Glass?, 22 PAC. L.J. 1 (1990).

159. See generally DeSilva, Droit Moral and the Amoral Copyright: A Comparison of Artists' Rights in France and the United States, 28 Bull. CopYRIGHT SOC'Y U.S.A. 1 (1980); Dianiond, Legal Protection for the 'Moral Rights' of Authors and other Creators, 68 Trademark ReP. 244 (1978); Roeder, The Doctrine of Moral Right: A Study in the Law of Artists, Authors and Creators, 53 HARV. L. REV. 554 (1940).

160. See Note, Protcction of Art Work Through Artists' Rights: An Analysis of State Law and Proposal for Change, 38 AM. U.L. Rev. 855 (1989).

161. See Carmenaty, Terry Gilliam's 'Brazil': A Film Director's Question for Artistic Integrity in a Moral Rights Vacuum, 14 ColUm. J.L. \& ARTs 25 (1989). 
white motion pictures, ${ }^{162}$ and public demands for the destruction or relocation of monumental sculptures. ${ }^{163}$

The connection between "moral rights" and the complex values associated with the Romantic conception of "authorship" is clear. In the words of one treatise:

The primary justification for the protection of moral rights is the idea that the work of art is an extension of the artist's personality, an expression of his innermost being. To mistreat the work of art is to mistreat the artist, to invade his area of privacy, to impair his personality. ${ }^{164}$

Another commentator puts the proposition differently, arguing that behind moral rights is the behief that "authors" are "almighty creators who pour particular meanings into tlieir creations and therefore inherently have undisputed authority over the uses and interpretations of those creations." 165

Given this genealogy, moral rights (unlike other copyright interests) are not in the marketplace; they are inalienable, although subject to waiver in particular instances. Such a legal apphication of "authorship" can only impede the free commerce in intellectual and artistic productions that Anglo-American copyright traditionally has fostered.

In effect, moral rights represent a charter for private censorship. ${ }^{166}$ They put the force of legal sanction behind one of the cultural functions of the "authorship" construct identified by Michel Foucault in What Is an "Author"?:

[I]f we are accustomed to present the author as a genius, as a perpetual surging of invention, it is because, in reality, we make him function in exactly the opposite fashion .... The author is ... the ideological figure by which one inarks the manner in which we fear the proliferation of ineaning. ${ }^{167}$

162. See U.S. Copyright OfFice, Technological Alterations to Motion Pictures, at 149-64 (Mar. 1989) (summarizing motion picture director's arguments and responses to them).

163. See Serra, Issues \& Commentary: "Tilted Arc" Destroyed, ART IN AMERICA, May 1989, at 34, reprinted in 14 Nova L. REv. 421 (1989); Brooks, 'Tilted Justice': Site-Specific Art and Moral Rights after U.S. Adherence to the Beme Convention, 77 CALIF. L. REV. 1431 (1989).

164. 1 J. Merryman \& A. Elsen, LAw, Ethics, and the Visual ArTs 145 (2d ed. 1987).

165. Beyer, Intentionalism, Art, and the Suppression of Innovation: Film Colorization and the Philosophy of Moral Rights, 82 Nw. U.L. REv. 1011, 1027 (1988). In a similar vein, Edward Damich has noted the intimate connections between "personality" theories of "moral rights" and the "natural law" theories generally. See Damich, The Right of Personality: A Common Law Basis for the Protection of the Moral Rights of Authors, 23 GA. L. REv. 1, 61 (1988).

166. See generally Gordon, Towards a Jurisprudence of Benefits: The Norms of Copyright and the Problem of Private Censorship, 57 U. CHI. L. REv. 1009 (1990). We may be reminded here of the not-so-remote origins of copyright in the institutions of official censorship. See generally $\mathbf{B}$. KAPLAN, supra note 10, at 1-6.

167. M. Foucault, supra note 60 , at 159. 
In many of the episodes surveyed in earher sections of this Article, a discernable pattern emerged in which the law's embrace of Romantic "authorship" has led to both the commodification of creative products and the disempowerment of their creators and consumers. Whatever we may think of the cultural implications of this pattern, ${ }^{168}$ a movement toward "authors" " moral rights in the Umited States does not appear to fit that pattern. However, just such a movement is underway.

Moral rights were a considerable focus of interest in the discussions leading up to the adoption of the Berne Convention Implementation Act of $1988 .{ }^{169}$ The Act made it possible for the United States to adhere to the 1971 Paris Act of the Berne Convention for the Protection of Literary and Artistic Works by modifying certain aspects of American law to comply with the Convention "minima." Although Article 6 of the Convention appears to require member countries to recognize the attribution and the integrity rights, ${ }^{170}$ publishers and other commercial distributors vigorously opposed any imcorporation of these rights into American law. ${ }^{171}$ As a result, Congress took no legislative action in 1988 to imtroduce such provisions into the scheme of copyright, pursuant to its minimalist approach to Berne adherence. ${ }^{172}$ Indeed, reflectimg the political compromise that underlay American adherence to Berne, the legislative history was drafted to emphasize that "the implementing legislation is completely neutral on the issue of whether or how protection of the rights of paternity and integrity should develop in the future." 173

168. For the notion that moral rights may be inimical to values of innovation and free expression, see Beyer, supra note 162; Gorman, Federal Moral Rights Legislation: The Need for Caution, 14 Nova L. ReV. 435 (1990).

169. Pub. L. No.100-568, 102 Stat. 2853 (1988).

170. See S. RICKETSON, supra note 29 , $\$ \S 8.102-8.116$, at 467-76.

171. See, e.g., Berne Convention Implementation Act of 1987: Hearings on H.R. 1623 before the House Judiciary Subcomm. on Courts, Civil Liberties and the Administration of Justice, 100th Cong., 1st and 2d Sess. $331-84$ (1988) (statement and testimony of David Ladd on behalf of the Coahition to Preserve the American Copyright Tradition).

172. See House Judiciary COMm., Berne Convention Implementation Act of 1988, H.R. Rep. No. 609, 100th Cong., 2d Sess. (1988). This approach entailed "modify[ing] American law minimally to place it im compliance with the provisions of the Berne Convention ...." Id. at 20 . The Congress determined that while "there is no single Federal statute relating specifically to "moral rights' ... there are other members of Berne that inpose even more limited protection. ... [T] here are substantial grounds for concluding that the totality of U.S. law provides protection for the rights of paternity and integrity sufficient to comply with $6 b i s$, as it is applied by various Berne countries." Id. at 37-38.

173. Id. at 38-39 (empliasis in original); see also Berne Convention Implementation Act of 1988, Pub. L. No. 100-568, 102 Stat. 2853 (1988), § 3(b):

CERTAlN RIGHTS Not AFFECTED.-The provisions of the Berne Convention, the adlerence of the United States thereto, and satisfaction of United States obligations thereunder, do not expand or reduce any right of an author of a work, whether claimed under Federal, State, or the common law -

(1) to claim authorship of the work; or 
Legislative neutrality notwitlistanding, ensuing years liave seen real movement toward the reception of moral rights in the Umited States. Indeed, the first manifestations of the trend go back even furtlier to a line of cases that involve journalists and biograpliers seeking to quote from unpublished manuscript materials under the fair use doctrine. ${ }^{174}$ In decisions which eclo, without hiterally imvoking, the "droit de divulgation" of Frencl "moral rights" doctrine, ${ }^{175}$ American courts have conferred on copyriglit owners near-absolute power of control over unpublished works-no matter how newswortly or germane to a would-be users' scholarly projects. ${ }^{176}$ In effect, the courts are endorsing the use of copyriglit as a device to enforce private censorship in the name of "authorship."

Evidence of the trend toward the recognition of moral rights no longer is restricted to judicial actions. In 1990, Congress passed the first moral rights legislation in the history of American copyright-the Visual Artists Rights Act of 1990. Contained as Title VI of the Justice Improvements Act of 1990, 177 the Act provides protection for the patermity and integrity rights of certain graphic artists, sculptors, and photographers. ${ }^{178}$

(2) to object to any distortion, mutilation, or other modification of, or other derogatory action in relation to, the work, that would prejudice the author's honor or reputation.

174. The "fair use" doctrine, codified in section 107 of the 1976 Copyright Act, provides that under some circumstances what otherwise would be considered infringing acts are immunized from hability. See generally Patterson, Free Speech, Copyright, and Fair Use, 40 VAND. L. REv. 1 (1987).

175. See generally Ginsberg, French Copyright Law: A Comparative Overview, 36 J. CopYright SOC'Y U.S.A. 269, 275-76 (1989); O. LAL1GANT, LA DivUlgation DES OeUVRES ARTISTIQUES, LitTeraires et Musicales en Droit PosttTF Français (1983).

176. See, eg., Harper \& Row Publishers, Inc. v. Nation Enters., 471 U.S. 539 (1986) (denying applicability of "fair use" to unauthorized publication of quotations from unpublished memoirs of Gerald Ford); New Era Publications Int'1 v. Henry Holt \& Co., 873 F.2d 476 (2d Cir. 1989) (denying applicability of "fair use" to use of unpublisled writings of founder of Scientology movement in critical biography), cert. denied, 110 S. Ct. 1168 (1990); Salinger v. Random House, 811 F.2d 90 (2d Cir. 1987) (denying applicability of "fair use" to use of quotations from unpublished letters of noted author in literary biography), cert denied, 484 U.S. 890 (1987); see also Francione, Facing The Nation: The Standards for Copyright, Infringement, and Fair Use of Factual Works, 134 U. PA. L. Rev. 519 (1986); Leval, Fair Use or Foul? The Nineteenth Donald C. Brace Memorial Lecture, $36 \mathrm{~J}$. COPYRIGHT Soc'y U.S.A. 167 (1989); Leval, Toward a Fair Use Standard, 103 HaRV. L. REv. 1105 (1990); Miner, Exploiting Stolen Text: Fair Use or Foul, 37 J. CopYRIGHT Soc'y U.S.A. 1 (1989); Newman, Not the End of History: The Second Circuit Struggles with Fair Use, 37 J. CopYrigrt Soc'Y U.S.A. 12 (1989); Weinreb, Fair's Fair: A Comment on the Fair Use Doctrine, 103 HARV. L. REV. 1137 (1990).

177. Pub. L. No. 101-650, 104 Stat. 5128 (1990). This Act was signed into law on December 1, 1990.

178. To qualify for protection, a "work of visual art" must be "a painting, drawing, print, or sculpture, existing in a single copy" or all copies of which form part of a limited edition of 200 or fewer; to qualify as such a "work," a photograph must be "a still plotographic image produced for exhibition purposes only, existing in a single copy that is signed by the author, or in a limited edition 
Although the United States did not incorporate noral rights into copyright in connection with American adherence to the Berne Convention in 1988, adherence may have foreshadowed their future adoption..$^{179}$ In fact, it is reinarkable that the step was taken sooner rather than later, despite a lack of support fron any of the copyright industries. ${ }^{180}$ Indeed, the passage of the legislation is difficult to explain except as a legislative expression of unreconstructed faith in the gospel of Roinantic "authorship."

\section{Conclusion: What Does It All Mean-and Does It Matter?}

On the evidence just adduced in this account of copyright doctrine, there is no reason to believe that the superficial incoherence of the doctrine can be satisfactorily explained in terms of any underlying master concept-including "authorship." In the preceding pages, I pursued the Roinantic vision of "authorship" through the thickets of copyright doctrine and noted its talent to appear, disappear, and reconstruct itself seemingly at will-clianging its contours at each reappearance. In the end, however, I ain no nearer than at the outset to a conclusion about how and low much the "authorship" construct inatters.

There are at least two possible sets of conclusions that can be drawn from the preceding set of stories. One is that "authorship" does not inatter much-at least not in the way it usually is assuned to matter. "Authorship" has been (and continues to be) strategically invoked, suppressed, or revised to mediate the inherent and repetitive manifestations of the tension between access and ownership. But the function that "authorship" has played im the evolution of copyriglit doctrine cannot be characterized as neutral. To a point, the stories retold demonstrate that in the domain of intellectual property, "authorship" has remained what it was im eighteenth-century England-a stalking loorse for economic interests that were (as a tactical matter) better concealed than revealed, and a convemient generative metaphor for legal structures that facilitated

of 200 copies or fewer that are signed and consecutively numbered by the author." Works of commercial art are excluded, and the rights conferred are subjected to various cxceptions and made waivable (although not transferrable). Id. $\$ \S 602,603$.

179. Great Britain, the other major holdout against the trend toward the recognition of "moral rights," finally capitulated in its Copyright, Designs and Patents Act of 1988, which took effect in 1989. Adherence to the Berne Convention had the effect of exposing the United States to the "culture" of the Convention, which is rooted in the "authors' rights" tradition of Continental European law, and thus in the Romantic vision of "authorship." See Jaszi, note 87, at 58.

180. For a review of recent trends in copyright legislation, assessing the role of industry groups, and incorporating a pessimistic prediction as to the likelihood of the enactment of moral rights, see Olson, The Iron Law of Consensus, 36 J. COPYRIGHT Soc'Y U.S.A. 109, 126 (1989). 
the emergence of new modes of production for hiterary and artistic works.

Seeing through the concept in this way suggests that it would hardly be surprising if "authorship" continued to oscillate. The prevailing view of "authorship" is often that which best serves the immediate interests of copyright proprietors who distribute the works as commodities. The collective interests of the ultimate consumers of works inay be served as well. For although it is traditional to view copyright doctrine as a battle between the interests of copyright owners (who are only incidentally "authors") and copyright users, in practice, those interests are remarkably congruent. Both sellers and buyers have a considerable stake in the maintenance of an orderly market with plentiful supphies of new works at reasonable prices.

Unfortunately for this explanation, "authorship" has a way of appearing and disappearing inconveniently, at times and in places where it is difficult to relate its manifestations to commercial interests. In particular, the recent resurgence of "authorship" reasoning in the copyright doctrine, in decisions like Gracen and Stewart, and particularly in the field of moral rights, is hard to account for in this analysis. These developments suggest the alternative view: that Ronrantic "authorship" and its connotations are deeply embedded in legal consciousness and that this behef sometimes expresses itself in ways that are inconvemient, to say the least, for the commerce of intellectual property. Moreover, if these recent developnients are instances of the law taking "authorship" seriously, can we be sure that its evocations in Burrow-Giles or the work-for-hire cases are not?

In this alternative view, then, "authorship" inatters a great deal. Copyright doctrine's intermittent insistence on "authorship" for its own sake reflects the continuing, autonomous significance of the cluster of values associated with the tern froin its first appearances in English letters, mcluding individual self-proprietorship, creative autonomy, and artistic originality-values which were supplemented and enriched as the specifically Ronrantic vision of "autlorship" took form. Altliougl the dissemination of these values, along witl other aspects of possessive individualism, imitially facilitated the development of a commodity market in intellectual productions, their survival had the potential to interfere witl the further development and smooth functioning of tliat market. As such, "authorship" may not so much facilitate commodification as impede it. Tlius, the overall imcoherence of the law's account of "authorship" may be best understood as reflecting a continuing struggle between the economic forces that (at least in the abstract) would be best served by 
the further depersonalization of creative endeavor and the ideological persistence of an increasingly inefficient version of individualism.

Perhaps it is fairest to admit that neither explanation truly accounts for the twists and turns of "authorship" in copyright doctrine. Perhaps soine combination of the two is required to explain its peregrinations. In sum, "authorship" is simultaneously an artifact of the marketplace in commodity art and a throwback to early, pre-imdustrial ideas of the artist's relation to society. Thus regarded, "authorship" contains within itself the contradiction at the base of all copyright doctrine. The conflict is not the familiar opposition between ownership and access, but the more fundamental, generative tension between the colleetivism of the marketplace and the prerogatives of the autonomous individual. 